\title{
Orogeny, migmatites and leucogranites: A review
}

\author{
MichaEL BROWN \\ Laboratory for Crustal Petrology, Department of Geology, University of Maryland, \\ College Park, MD 20742, U.S.A. \\ e-mail:mbrown@geol.umd.edu
}

The type of $P-T-t$ path and availability of fluid $\left(\mathrm{H}_{2} \mathrm{O}\right.$-rich metamorphic volatile phase or melt) are important variables in metamorphism. Collisional orogens are characterized by clockwise $P-T$ evolution, which means that in the core, where temperatures exceed the wet solidus for common crustal rocks, melt may be present throughout a significant portion of the evolution. Field observations of eroded orogens show that lower crust is migmatitic, and geophysical observations have been interpreted to suggest the presence of melt in active orogens. A consequence of these results is that orogenic collapse in mature orogens may be controlled by a partially-molten layer that decouples weak crust from subducting lithosphere, and such a weak layer may enable exhumation of deeply buried crust. Migmatites provide a record of melt segregation in partially molten crustal materials and syn-anatectic deformation under natural conditions. Grain boundary flow and intra- and inter-grain fracture flow are the principal grain scale melt flow mechanisms. Field observations of migmatites in ancient orogens show that leucosomes occur oriented in the metamorphic fabrics or are located in dilational sites. These observations are interpreted to suggest that melt segregation and extraction are syntectonic processes, and that melt migration pathways commonly relate to rock fabrics and structures. Thus, leucosomes in depleted migmatites record the remnant permeability network, but evolution of permeability networks and amplification of anomalies are poorly understood. Deformation of partially molten rocks is accommodated by melt-enhanced granular flow, and volumetric strain is accommodated by melt loss. Melt segregation and extraction may be cyclic or continuous, depending on the level of applied differential stress and rate of melt pressure buildup. During clockwise $P-T$ evolution, $\mathrm{H}_{2} \mathrm{O}$ is transferred from protolith to melt as rocks cross dehydration melting reactions, and $\mathrm{H}_{2} \mathrm{O}$ may be evolved above the solidus at low $P$ by crossing supra-solidus decompression-dehydration reactions if micas are still present in the depleted protolith. $\mathrm{H}_{2} \mathrm{O}$ dissolved in melt is transported through the crust to be exsolved on crystallization. This recycled $\mathrm{H}_{2} \mathrm{O}$ may promote wet melting at supra-solidus conditions and retrogression at subsolidus conditions. The common growth of 'late' muscovite over sillimanite in migmatite may be the result of this process, and influx of exogenous $\mathrm{H}_{2} \mathrm{O}$ may not be necessary. However, in general, metasomatism in the evolution of the crust remains a contentious issue. Processes in the lowermost crust may be inferred from studies of xenolith suites brought to the surface in lavas. Based on geochemical data, we can use statistical methods and modeling to evaluate whether migmatites are sources or feeder zones for granites, or simply segregated melt that was stagnant in residue, and to compare xenoliths of inferred lower crust with exposed deep crust. Upper-crustal granites are a necessary complement to melt-depleted granulites common in the lower crust, but the role of mafic magma in crustal melting remains uncertain. Plutons occur at various depths above and below the brittle-to-viscous transition in the crust and have a variety of 3-D shapes that may vary systematically with depth. The switch from ascent to emplacement may be caused by amplification of instabilities within (permeability, magma flow rate) or surrounding (strength or state of stress)

Keywords. Anatexis; granite emplacement; magma ascent; melt segregation; migmatite; orogeny; pluton.

Proc. Indian Acad. Sci. (Earth Planet. Sci.), 110, No. 4, December 2001, pp. 313-336

(C) Printed in India. 
the ascent column, or by the ascending magma intersecting some discontinuity in the crust that enables horizontal magma emplacement followed by thickening during pluton inflation. Feedback relations between rates of pluton filling, magma ascent and melt extraction maintain compatibility among these processes.

\section{Introduction}

Much of Earth's crust comprises deformed metamorphic rock formed and modified during orogenesis. Orogens are open systems in which selforganized behavior enables efficient dissipation of energy, manifest in feedback relations among deformation, metamorphism and anatexis (Brown and Solar 1998a; Hodges 1998). How feedback is recorded relates to properties of rocks, particularly the rheology. As suggested by Haugerud and Zen (1991), metamorphic rocks are flight recorders recovered from the wreckage of an orogen that can tell us something of the history of the passage of material through the orogen. On the flight through $P-T$ space, what happens to a particular rock is determined by the reaction lines/fields crossed along the prograde (increasing $T$ ) stage, whether any of these reaction lines/fields are recrossed along the retrograde (decreasing $T$ ) stage, and whether any fluid generated along the prograde segment of the path $\left(\mathrm{H}_{2} \mathrm{O}\right.$-rich metamorphic volatile phase or melt) is retained to allow reaction reversal along the retrograde segment. The critical step for nucleation of product phases and the rate of dissolution of refractory phases are additional factors. Field relations, rock fabrics and microstructures, mineral assemblages, reaction textures, mineral compositional variation and isotope data provide a record of the rock history (e.g. Brown 1993; Brown and O'Brien 1997; Brown 2001). Our ability to read the evidence preserved in metamorphic rocks is critical to understanding the history they record, which is essential to constraining alternative models of orogenesis. This is a prerequisite to improving our understanding of orogenic processes.

Although granites are found in a variety of plate tectonic settings (Atherton and Tarney 1979; Pitcher 1993), the principal environments of mountain building and crustal melting are continental arcs and collision zones (Brown et al. 1995a). Evidence of crustal melting in orogens is present at all scales, from microfracturing in residual quartz and inferred melt pseudomorphs in grain boundary pores in protolith materials (e.g. Connolly et al. 1997; Holness and Clemens 1999; Rosenberg and Riller 2000; Watt et al. 2000; Marchildon and Brown 2001) to plutonic belts the length of lithosphere plate boundaries (Kay and Rapela 1990; Harmon and Rapela 1992) and major collisional mountain belts (LeFort 1986; Harrison et al.
1997). Continental collision is occurring today in the subduction of India beneath the Eurasian tectonic plate to form the Himalayas and the Tibetan Plateau (Hodges 2000), and is widely inferred for many major Phanerozoic orogens. Subduction precedes collision, so that the degree of preheating during ocean closure may be an important variable in the thermal evolution of collisional orogens (Jamieson et al. 1998). The process of melt generation and segregation, and magma extraction, ascent and emplacement leads to differentiation of the continental crust into a depleted lower crust and an enriched upper crust (e.g. Brown et al. 1995a). However, in continental arcs there is a significant involvement of mantle-derived melts in the generation of calc-alkaline granites (e.g. Patiño Douce 1999), which means that granite magmatism in continental arcs results in crustal growth. The role of lithosphere delamination, slab detachment and mantle magmatism in the evolution of collision zones requires further study.

\section{An overview of orogens and melting}

Geodynamics is driven by heat released from Earth's core and radioactive decay. Heat transport, by convection, conduction or advection, determines the $T$ attained at depth in the lithosphere and, therefore, the type of crustal metamorphism, whether melting occurs, and the rheological behavior. During orogeny, tectonic and magmatic processes advect heat to shallower levels in the deforming lithosphere, and melting and melt transport redistribute radioactive elements. These processes control the evolution and differentiation of continental crust, and create depleted granulites typical of the lower crust and upper-crustal granites. Orogens are systems far from equilibrium that exhibit a coherent arrangement of features in space and time - they are dissipative structures that provide mechanisms for dispersal of the internal energy of Earth (Brown and Solar 1998a; Hodges 1998).

Orogenic evolution in collision zones comprises a period of crustal thickening, a period during which thickening and exhumation commonly are balanced, and a period of collapse (Dewey 1988; Vanderhaeghe and Teyssier 2000), although there are many variables in the evolution of orogens (e.g. Ellis and Beaumont 1999). Since strain in orogenic belts does not appear to be linked in a simple 
way to plate kinematics, other factors contribute to deformation of the continental crust, particularly gravity-driven flow. Thermomechanical numerical modeling of the dynamic evolution of convergent orogens driven by subduction provides constraints on the physical conditions required to generate temperatures high enough for crustal anatexis, and allows investigation of the rheological structure leading to mechanical decoupling between the weakened crust and the subducting plate (Royden 1993; Thompson et al. 1997; Huerta et al. 1998; Jamieson et al. 1998).

Geological studies in ancient orogens (e.g. Brown 1994; Brown et al. 1995a) and geophysical studies in active orogens (e.g., Nelson et al. 1996; Partzsch et al. 2000) have been interpreted to indicate that the part of the crust is in a partially molten state during orogenesis. The presence of melt may weaken the crust sufficiently to decouple it from the subducting lithosphere plate (e.g. Burg et al. 1994; Vanderhaeghe et al. 1999; Vanderhaeghe and Teyssier 2001), and may enable exhumation of deeply buried crust (e.g. Hollister 1993; Brown and Dallmeyer 1996). Thus, it is important to understand the rheology of partially molten crust, to determine the mechanical effects of melt in the crust and to evaluate the consequences of these effects during orogenic evolution (Davidson et al. 1994; Handy et al. 2001). There are feedback relations between heat and melting and melt transport and deformation (Brown and Solar 1998a). Thus, crustal melting and melt segregation, extraction, ascent and emplacement are inevitably linked with the developing tectonic structure as a principal energy dissipation mechanism in the lithosphere.

One spatial feature of orogens that requires explanation is the variation in volume of exposed granite. Examples of granite-rich orogens include the Appalachian Mountain Belt, the European Variscan belt and the Lachlan fold belt of SE Australia, whereas granite-poor orogens include the Scandinavian Caledonides and the CentralWestern Alps. One explanation put forth for the variation in amount of granite is the contrasting fertility of the major rock types involved in the different orogens (Vielzeuf et al. 1990). Where orogenic processes mainly rework an older basement, composed of differentiated crust, significant granite magmatism is unlikely (e.g. Sawyer 1998). In contrast, orogens that incorporate large quantities of fertile sedimentary rocks offer the possibility of voluminous granite production.

The premier analog for many ancient, deeply eroded collisional orogens is the HimalayanTibetan system. Combined seismic reflection profiling, wide-angle reflection, broadband teleseismic studies, and magnetotelluric surveys yield coinci- dent observations of reflection bright spots, a low velocity zone, and a low resistivity zone. These features coincide with an area of elevated heat flow. This remarkable collection of data has been interpreted to suggest a molten layer capped at $15-18 \mathrm{~km}$ depth by a semi-continuous horizon of granite plutons within the crust of southern Tibet (Nelson et al. 1996; Alsdorf et al. 1998; Alsdorf and Nelson 1999; Partzsch et al. 2000). This interpretation is supported by analogy with the exposed geology. It appears that the crust in southern Tibet may act like a 'water bed', whereby the elevated topography of the Tibetan Plateau is maintained above a viscous middle crust under hydraulic pressure, principally as a result of the 'extensive presence of melt'. In this model, the upper crust is supported on a lower viscosity (melt-bearing) layer that flows laterally when loaded, and orogenparallel flow of the Tibetan Plateau is one manifestation of this phenomenon. Application of the 'water bed' model to other orogens may yield insight into previously intractable phenomena such as strain partitioning into contractional structures at depth and coeval extensional structures at a higher level in the crust during overall convergent orogenic deformation. There is little erosion at the surface across the Tibetan Plateau, so that if collision slows to a stop, the likely response may be extension and preservation of the middle crust as a migmatite belt. Thus, Tibet might be an appropriate analog for some high- $T$ - low- $P$ metamorphic belts particularly those commonly associated with voluminous granite plutons (Gerdes et al. 2000; Ledru et al. 2000).

It is an open question whether significant meltproducing perturbations arise from 'tectonics as usual' or from special mantle events (cf. Patiño Douce 1999; Thompson 1999). There is, however, clear evidence for melting during collapse late in the evolution of many orogens formed by collisional processes, popularly related to lithosphere delamination or slab detachment (von Blanckenburg and Davis 1995; Davis and von Blanckenburg 1995; Barboza et al. 1999; Handy et al. 1999). Collapse is recorded by metamorphic mineral parageneses that evidence decompression (e.g. Brown 1993) and the close age span of mineral geochronometers that cover a range of closure temperatures (Baldwin et al. 1993). Implied rapid cooling, inferred to reflect fast exhumation, is common in Phanerozoic orogens (e.g. Brown and Dallmeyer 1996; Zeck 1996), but may be less common in ancient orogens.

One model for the large ion lithophile element depletion of crustal rocks during granulite facies metamorphism is that of melt loss (e.g. Vielzeuf et al. 1990). In this model, granulite-facies metamorphism and crustal anatexis are coupled 
processes that result in chemical differentiation of continental crust. For example, on the southern margin of Variscan Europe, the Permian granites of the Strona-Ceneri zone commonly are regarded as the fugitive melt that complements residual stronalites of the adjacent Ivrea zone (e.g. Schnetger 1994). Additional information about processes in the lowermost crust may be deduced from studies of xenoliths of crustal materials brought to the surface in lavas (Zeck 1970; Cesare et al. 1997), and partial-melting processes recorded in xenoliths can be compared with those in exposed exhumed crust (e.g. Braun and Kriegsman 2001). Geochemical methods enable comparison between migmatites and plutonic granites (Brown and D'Lemos 1991; Williamson et al. 1997; Pressley and Brown 1999; Brown and Pressley 1999; Solar and Brown 2001b), and between exposed crust and lower crust brought up in xenolith suites in volcanic rocks (Rudnick and Presper 1990; Rudnick 1992; Rudnick and Fountain 1995), although such suites may be biased in favor of better preserved mafic rock types. Further, migmatite terranes may be compared with plutonic granites to evaluate the question of whether migmatites are feeder zones for granites (Brown and Solar 1999; Del Moro et al. 1999; Solar and Brown 2001b). There is also the issue of whether metasomatism may play a role in the chemical and rheological evolution of the crust (Franz and Harlov 1998; Harlov et al. 1998).

During clockwise $P-T$ evolution of orogenic belts, $\mathrm{H}_{2} \mathrm{O}$ is recycled as rocks cross dehydration melting reactions, with the $\mathrm{H}_{2} \mathrm{O}$ being transported in melt (Holk and Taylor 1997), and suprasolidus decompression-dehydration reactions at low $P$, where $\mathrm{H}_{2} \mathrm{O}$ is released that may promote new melting in adjacent rocks under appropriate circumstances (Thompson 2001a, 2001b). During retrogression above the wet solidus, back reaction between melt and residue may happen if the cooling path approximates the heating path, which may cause modification of mineral assemblage, chemistry and texture (Kriegsman and Hensen 1998; Kriegsman 2001a). It is likely that an $\mathrm{H}_{2} \mathrm{O}$ fluxed zone straddles the anatectic front, reflecting exsolution of $\mathrm{H}_{2} \mathrm{O}$ during crystallization of stagnant melt arrested close to the anatectic front. This exsolved $\mathrm{H}_{2} \mathrm{O}$ causes retrogression typical of migmatite terrains in collisional zones, particularly the late growth of muscovite at the expense of sillimanite (e.g. Solar and Brown 2001b).

Magma ascent and emplacement has been a controversial topic for the past decade. Pluton emplacement mechanics are investigated in the field and by modeling (e.g. Brun et al. 1990; Brown and Solar 1998b; Benn et al. 1998; Cruden 1998). However, the question of what causes the switch from magma ascent to emplacement is an issue that needs attention (e.g. Brown and Solar 1998b; Miller and Paterson 1999). Within plutons, we are beginning to understand better flow processes in magma (e.g. Petford and Koenders 1998a, compositional and thermal convection (e.g. Weinberg et al. 2000) and the role of deformation in the extraction of residual melts, both by shearing and by compaction (e.g. Park and Means 1996). Finally, rates of melt extraction from partially molten crust, magma ascent and pluton filling all are much faster than previously thought (Clemens and Mawer 1992; Clemens 1998; Cruden 1998; Tanner 1999; Thompson 1999; Harris et al. 2000; Petford et al. 2000), and linked by feedback relations that moderate the rates to maintain overall compatibility.

\section{Thermal structure of orogens}

The thermal structure of post-Archaean orogens reflects variations among internal heat production, advection, diffusion and basal heat flux. The normal orogenic evolution of subduction, followed by collision that leads to increased crustal thickening and decreased convergence rate, allows selfheating of the thickened orogen; clockwise $P-T$ paths are characteristic. The following processes are important: material transfer advecting hot crust to shallow depths, and heat conduction to the surface by syntectonic erosion (Jamieson et al. 1998); increased radioactive heat generation due to thickening, important if high heat-producing units are present (Chamberlain and Sonder 1990; Gerdes et al. 2000); dissipation of mechanical energy generated during deformation (Scholz 1980; Barr and Dahlen 1989; Molnar and England 1990); and, increased strain rates due to weakening in the presence of melt (Rutter 1997). The initial distribution of radioactive heat production with depth, including the location and proportion of any anomalous heat-producing layers, is an important variable (Jamieson et al. 1998). Heat advected with mantle-derived magmas is important in the development of continental arcs, like the Andes, but the apparent smaller volume of mafic plutonic rocks exposed in ancient collisional belts means the role of mantle-derived magma in the thermal evolution of these belts is not well constrained. A combination of these processes strongly perturbs the geothermal gradient by displacing isotherms toward the surface, creating a thermal antiform with a near-isothermal core (Royden 1993; Thompson et al. 1997; Huerta et al. 1998; Jamieson et al. 1998), and generating temperatures exceeding the wet solidus and the stability of mica and amphibole in common crustal rocks (Brown and Solar 1999). 


\section{Melting, strain localization and pluton-driven metamorphism}

Experimental melting of natural rock samples has demonstrated the importance of reactions involving breakdown of mica and amphibole (dehydration melting; Thompson 1999). Such reactions, which have steeply positive $\mathrm{d} P / \mathrm{d} T$ slopes, are crossed during the prograde part of the $P-T$ evolution (figure 1). One consequence of regional melting along clockwise $P-T$ paths is that part of the orogenic crust 'must' be molten for a substantial portion of the evolution, perhaps for periods of millions of years, which is likely to have significant geodynamic implications (Vanderhaeghe and Teyssier 2000). During regional melting, transport of melt out of the source region takes with it $\mathrm{H}_{2} \mathrm{O}$, which has consequences for the evolution of the lower crust and hydration reactions in the upper crust once the transported $\mathrm{H}_{2} \mathrm{O}$ is exsolved on crystallization of the melt.

Melting proceeds in a stepwise fashion (figure 1), beginning at the wet solidus, which is crossed at middle to lower-crustal depths in collisional orogens. Melt production at the wet solidus is limited by the amount of $\mathrm{H}_{2} \mathrm{O}$-rich metamorphic volatile phase present in the limited porosity remaining under amphibolite facies conditions. Muscovite dehydration (figure 1) is likely to be the major melt-producing step in the evolution of many orogens (Patiño Douce 1999), and is particularly important in the metapelitic component of the supracrustal succession in orogens (Patiño Douce and Harris 1998). Without an ingress of a $\mathrm{H}_{2} \mathrm{O}$-rich metamorphic volatile phase, the amount of melt produced generally is limited by the amount of muscovite in the protolith. Although the muscovite-biotite schist studied by Patiño Douce and Harris (1998) produced 20 vol.\% melt within $25^{\circ} \mathrm{C}$ of the solidus at $P$ of $6 \mathrm{kbar}$, the muscovitebiotite gneiss studied by Castro et al. (2000) produced melt at a slower but constant rate with increasing temperature to yield $\sim 15$ vol. $\%$ melt by $900^{\circ} \mathrm{C}$ at 6 kbar. High (and ultra-high) temperature metamorphism may involve biotite dehydration (figure 1), which is particularly important for the greywacke component of supracrustal successions. Thus, temperature is buffered sequentially by the latent heat of melting required at the wet solidus, and during muscovite dehydration melting and biotite dehydration melting.

Recent modeling (Harrison et al. 1998; Leloup et al. 1999; Nabelek and Liu 1999) suggests shear heating may be more important than realized previously (Brun and Cobbold 1980; Fleitout and Froidevaux 1980) as a contributor to the heat budget and thermal structure of orogens. Although shear heating in lithosphere-scale fault zones can

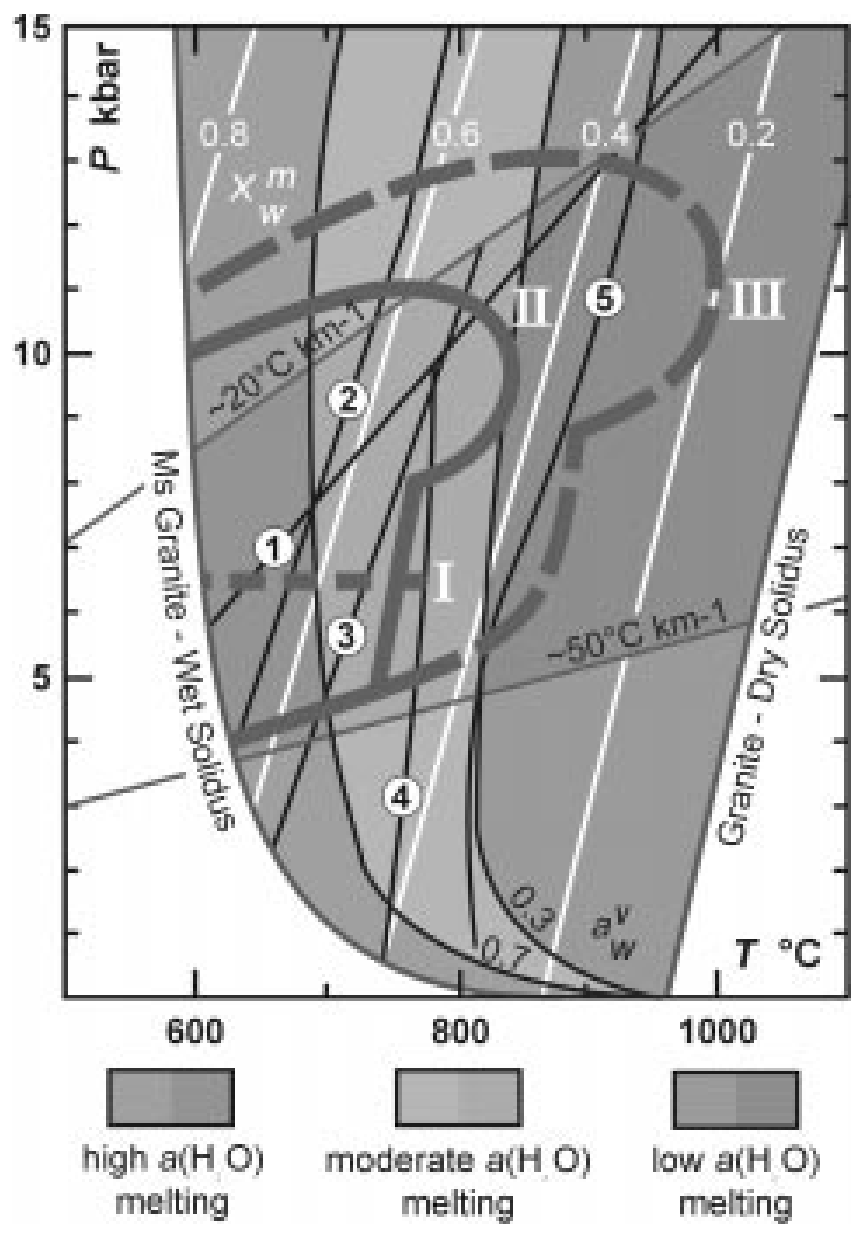

Figure 1. $\quad P-T$ diagram of the anatectic zone, that region in $P-T$ space above the wet solidus for crustal rocks of granitic composition in which melt may be present. Reaction (1) is $\mathrm{Ky} \rightarrow$ Sil, the Ms granite - wet solidus is from Huang and Wyllie (1981); reaction (2) $\mathrm{Ms}+\mathrm{Ab}+\mathrm{Qtz} \rightarrow \mathrm{Kfs}+\mathrm{Als}$ $+\mathrm{L}$ is from Petö (1976) and marks the lower $T$ limit of plagioclase reactions (Thompson and Tracy 1979); reaction (3) $\mathrm{Ms}+\mathrm{Pl}+\mathrm{Qtz} \rightarrow \mathrm{Kfs}+\mathrm{Sil}+\mathrm{Bt}+\mathrm{L}$ is from Patiño Douce and Harris (1998); reaction (4) $\mathrm{Bt}+\mathrm{Pl}+\mathrm{Als}+\mathrm{Qtz} \rightarrow \mathrm{Grt}$ $+\mathrm{Kfs}+\mathrm{L}$ is from LeBreton and Thompson (1988); and, reaction (5) $\mathrm{Bt}+\mathrm{Pl}+\mathrm{Qtz} \rightarrow \mathrm{Opx}+\mathrm{Grt}+\mathrm{Kfs}+\mathrm{L}$ is from Vielzeuf and Montel (1994). The symbol $X_{w}^{m}$ is used to denote the mole fraction of $\mathrm{H}_{2} \mathrm{O}$ in the melt and is considered to equal the activity of $\mathrm{H}_{2} \mathrm{O}$ in the melt (Burnham 1979); isopleths of $X_{w}^{m}$ are from Thompson (1996). The symbol $X_{w}^{v}$ is used to denote activity of $\mathrm{H}_{2} \mathrm{O}$ in the volatile phase, whereas $\mathrm{a}\left(\mathrm{H}_{2} \mathrm{O}\right)$ refers to water activity in the environment; isopleths of $X_{w}^{v}$ are from Thompson (1996). Schematic $P-T$ paths: I. Isobaric heating - cooling path characteristic of deep contact metamorphism; II. Stepped clockwise path (based on Brown and Dallmeyer 1996); and, III. Stepped clockwise path at ultrahigh T (based on Brown and Raith 1996; Raith et al. 1997)

induce a modest increase in temperature, results of modeling continental strike-slip shear zones suggest that shear heating in the upper mantle may induce lower crustal melting (Leloup et al. 1999). The possibility of such melting depends on upper mantle rheology and on the fertility of the lower crust, but the modeling predicts crustal 


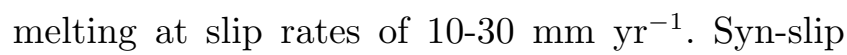
ascent of the melt will enhance the rising temperature in shallower parts of the fault zone. Further, shear heating should induce strain localization in the deeper parts of fault zones, consistent with observations from deeply eroded ancient orogens. This raises the issue of the relationship between localization of strain and accumulation of melt (e.g. Brown and Solar 1998a). At high fluid pressure, deformation is dilatant (i.e. pore space is created and permeability is higher). Thus, zones of localization should attract melt and become the principal ascent conduits in the viscous crust. However, shear zones are weaker than wall rock, a contrast that increases with decreasing depth in the crust. Thus, shear zones might have a tendency to expel melt as the contrast in strength exceeds some critical value. In shallower crust, the location of plutons between faults (Paterson and Schmidt 1999) is consistent with the expectation that where faults overlap the intra-jog region is a mean stress low and potentially a site of melt accumulation and pluton construction (cf. Connolly and Cosgrove 1999).

Temperatures at shallower structural levels in rocks below the solidus may be buffered by crystallization of melt that has escaped from the melting zone at lower structural levels. As a consequence, a popular paradigm for high- $T$ - low- $P$ metamorphism has been advection of heat with migrating magma, the magma having been generated by crustal anatexis in regions of thickened continental crust (DeYoreo et al. 1989). The term 'plutondriven metamorphism' can be used to describe the metamorphic product of such a process; it refers to upper-crustal metamorphism in which the highergrade metamorphic zones appear to mimic pluton contacts, the implication being that the metamorphism is pluton-related (DeYoreo et al. 1991). Such a term is more appropriate than "regional contact metamorphism" (Kays 1970) since magmatic underplating, which is a common paradigm for granulite-facies metamorphism, also can be thought of as regional contact metamorphism. There is no doubt that plutons can be an important contributor to the driving force for high- $T$ - low- $P$ metamorphism, particularly in the upper crust where commonly there is a spatial relationship between plutons and isograds. The maximum thermal effect of pluton-driven metamorphism in the upper crust occurs when intrusions are contemporaneous, but significant heating will occur even when intrusions are temporally separate (Barton and Hanson 1989). If the granites are crustally derived, however, the first order problem is what causes crustal melting, and we should avoid following casually an implied cause and effect (Brown and Solar 1999; Gerdes et al. 2000).
For illustrative purposes only, I take as an example the Devonian Acadian metamorphism of the Northern Appalachians, USA (see the papers by Brown and Solar 1998b, 1999; Brown and Pressley 1999; Pressley and Brown 1999; Solar and Brown 1999, 2001a, 2001b). The Acadian metamorphic belt is characterized by elevated modernday heat flow $\left(\sim 65 \mathrm{~m} \mathrm{Wm}^{-2}\right)$ and high heat production $\left(\sim 3.5 \times 10^{-6} \mathrm{Wm}^{-3}\right)$. Metamorphic field gradients suggest high-to-moderate rates of temperature change during metamorphism, but reveal only small variations in pressure. The stratigraphic sequence includes formations with high heat production, a consequence of high $\mathrm{U}$ and Th contents fixed in strongly reduced sediments of the precursor anoxic basin (Chamberlain and Sonder 1990). Oblique translation during contractional deformation thickened the stratigraphic sequence and displaced isotherms toward the surface, to create the thermal structure imaged by the 'migmatite front', essentially an isothermal surface given the high $\mathrm{d} P / \mathrm{d} T$ slope of the beginning of melting in most crustal protoliths (Brown and Solar 1999). Melt transport to progressively shallower crustal levels by differential stress-induced processes and buoyancy helps propagate the thermal corridor upward by advecting of heat into the upper crust (Brown and Solar 1999).

Once melt is trapped and crystallized in a pluton, its source can be traced using isotopic fingerprinting, so that we can assess the volume of melt derived from different sources in the crust. This information can be used to determine if the thermal perturbation associated with hightemperature metamorphism extended to the Moho, reflected in voluminous granite magmatism from lower-crustal or mixed (crust and mantle) sources, or was damped in the lower crust.

Again referring to the Acadian metamorphic belt of the northern Appalachians, in western Maine eastern New Hampshire the absence of a significant volume of granite with a geochemical signature indicating derivation from basement inferred to underlie the Central Maine belt (e.g. Lathrop et al. 1996; Pressley and Brown 1999; Brown and Pressley 1999) is consistent with calculated intermediate-to-low reduced heat flow from the lower crust and mantle (Chamberlain and Sonder 1990). This implies low thermal gradients in the lower crust under assumed granulite facies conditions. Thus, Acadian orogenesis involved redistribution of energy and mass within the crust, rather than addition of energy and mass by mantle processes. However, in circumstances where granites image lower-crustal sources, particularly older basement, the heat required for melting implies some mantle involvement, although this may not be a simple underplate (Brown and Dallmeyer 
1996; Barboza et al. 1999; Handy et al. 1999; Leloup et al. 1999). Indeed, according to the modeling of Leloup et al. (1999), partial melting of the upper mantle during strike-slip displacement along a lithospheric fault zone could occur in the presence of small amounts of fluid, with ascent of the resultant melts along the fault zone contributing to the upward displacement of isotherms and causing crustal melting.

At the implied high geothermal gradients characteristic of collisional orogens, the distribution of strength in the crust is variable according to the magnitude of the geothermal gradient and lithological make-up. Thus, large contrasts in strength may occur across rheologically defined and lithological boundaries (Ord and Hobbs 1989). Lateral variations in geothermal gradient implied by the thermal antiform produce shallow-dipping interfaces between units of highly contrasting strength that abut a zone of plastic yield. Further, anatexis is expected to have a profound effect on the rheology of crust, and hence the deformation history of orogens. The thermal antiform characteristic of regional metamorphic belts would inevitably cause strain localization in the deeper parts of collisional orogens. Pervasive melt flow is possible within the thermal antiform outlined by the 'migmatite front', because of the difference in temperature between melt-producing reactions and the wet solidus (Brown and Solar 1999; Weinberg 1999). Heat advected with migrating melt may promote amplification of this thermal antiform in a feedback relation extending the zone of plastic deformation and melt migration to shallower levels (e.g. Brown and Solar 1999), propagating upward the weakening front and promoting further amplification of the thermal antiform. Culminations in the thermal antiform may be sites of melt accumulation, creating perturbations from which magma may escape to form plutons. Although melting is a consequence of thermal evolution driven ultimately by tectonics, the resultant plutons may effect high$T$ metamorphism in the upper crust (e.g. Brown and Solar 1999).

In some orogens, anatectic melt has a role in enabling both uplift and exhumation of deep crust (Hollister 1993; Brown and Dallmeyer 1996). If the presence of melt in the middle crust is the facilitator, then the question of what vol.\% melt is necessary to cause these effects must be addressed. One area of current interest concerns the use of geophysical observations to quantify the vol.\% melt in the crust of active orogens (Partzsch et al. 2000), with interpretations calibrated on the basis of laboratory experiments that characterize the petrophysical properties of partially-molten rocks. The inferred minimum melt fraction to satisfy the data in the Central Andes, part of a continental arc, is $\sim 15$ vol.\%, which is four times greater than in either the Himalayan or Pyrenean collision zones, where $\sim 4$ vol.\% melt satisfies the data. Rushmer (2001) has suggested that the low volume of melt produced in the early stages of biotite dehydration may mean that it becomes trapped along grain boundaries and remains distributed at the grain scale until sufficient volume of melt to allow extraction is generated. This trapped melt may be a mechanism that weakens the crust during orogeny.

\section{Criteria used to infer that leucosomes are products of partially molten systems}

A primarily anatectic origin for many migmatites is intimated by their macrostructure (e.g. Brown 1973, 1994; Sawyer 1999), revealed by their microstructure (e.g. Cuney and Barbey 1982; Vernon and Collins 1988; McLellan 1989; Harte et al. 1991; Brown 1998; Sawyer 1999; Vernon 1999), suggested by geochemical data (e.g., Dougan 1979, 1981; Weber et al. 1985; Sawyer and Barnes 1988; Sawyer 1998), permitted by estimates of $P-T$ conditions (e.g. Ashworth 1985; Ashworth and Brown 1990; Vielzeuf and Vidal 1990), evidenced by textures that record dehydration melting (Waters 1988), and indicated by accumulation of quartzofeldspathic material in dilatant sites formed during syn-anatectic deformation of the protolith (e.g. Brown 1994, 1997; Sawyer 1994; Brown et al. 1995b; Brown and Rushmer 1997; Snoke et al. 1999; Vernon and Paterson 2000).

Two examples of dehydration melting are shown in figures 2 and 3 . In the first example, the peritectic product of the biotite dehydration melting reaction occurs in leucosome patches, which suggests some melt retention, although there is no back reaction, whereas in the second example the absence of leucosome suggests most of the melt has been extracted, at least from the volume exposed by the plane of section. Two examples of leucosome accumulation in dilatant sites are shown in figures 4 and 5, in which inter-boudin partitions and dilatant shear surfaces are inferred to have been sites of lower pressure into which melt accumulated.

Leucosome geometry in these migmatites is inferred to record evidence of active melt flow, rather than stagnant melt, if:

- bulk rock compositions are consistent with depletion in felsic components, implying that leucosome was not simply a product of in situ segregation during partial melting; and

- leucosomes preserve textures resulting from the presence of melt, such as euhedral phenocrysts/peritectic phases, textures that mimic solid-melt relations (quartz/feldspar films along grain boundaries, interstitial-xenomorphic 


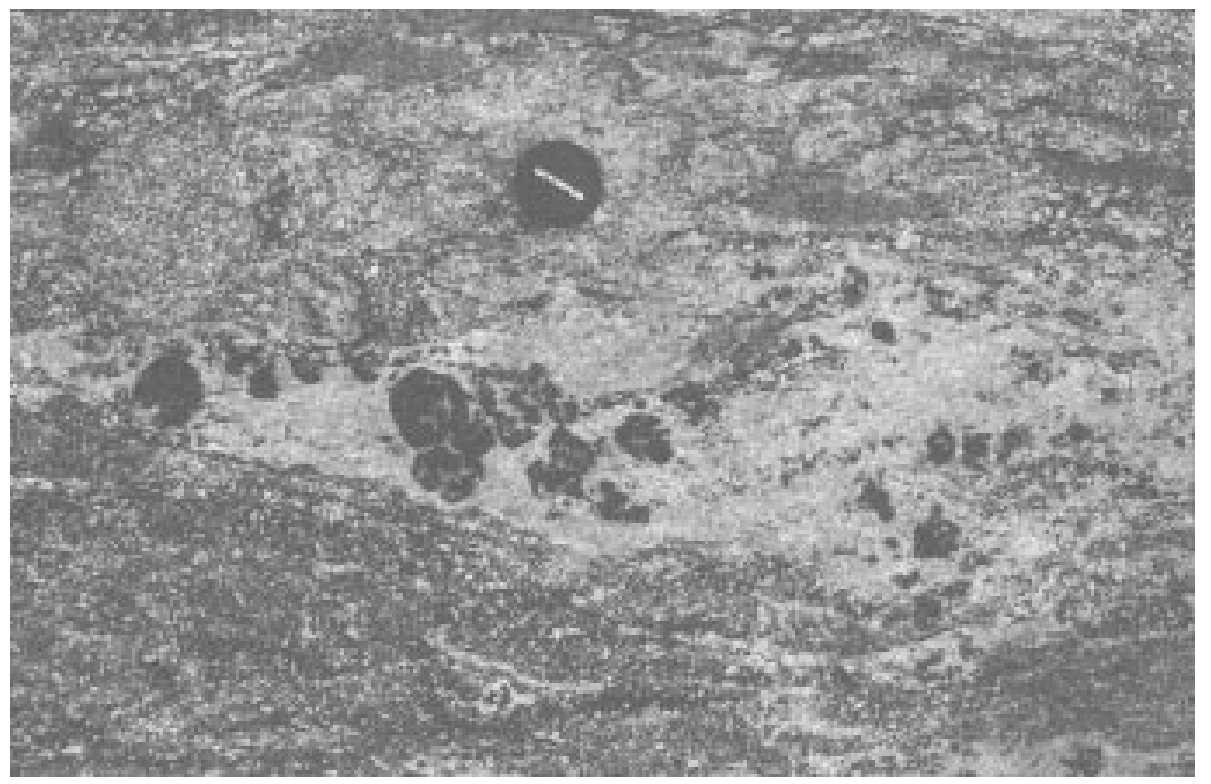

Figure 2. Dehydration melting in migmatitic granulite facies paragneisses. In this example, the peritectic product of the biotite dehydration melting reaction, euhedral garnet, occurs in leucosome patches, although there is no back reaction, which suggests accumulation of cumulate minerals and melt loss. Enseada Azul Beach, Guarapari, Espirito Santo, Brazil.

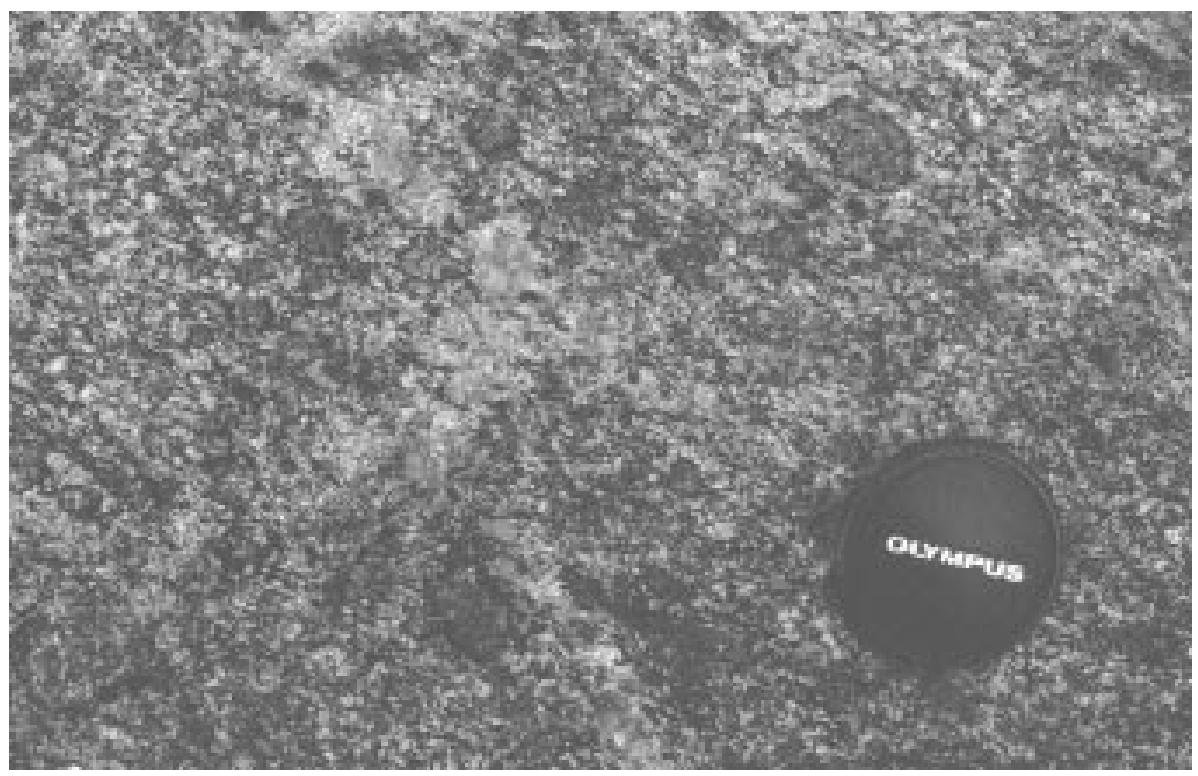

Figure 3. Dehydration melting in migmatitic granulite facies paragneisses. In this example, the absence of discrete leucosome suggests the melt was only locally segregated into patches, but segregation was sufficient that back reaction, although evidenced by the thin biotite rind on garnet, was minimal. Enseada Azul Beach, Guarapari, Espirito Santo, Brazil.

quartz, residual quartz in feldspar), meltsolid reaction textures and fractured residual grains (e.g. Cuney and Barbey 1982; Vernon and Collins 1988; Powell and Downes 1990; Harte et al. 1991; Ellis and Obata 1992; Schnetger 1994; Nyman et al. 1995; Brown and Dallmeyer 1996; Hartel and Pattison 1996; Carson et al. 1997; Brown 1998; Sawyer 1999, 2001; Vernon 1999; Watt et al. 2000; Marchildon and Brown 2001; and Brown 2001).

The simple presence of euhedral crystals alone clearly is not sufficient, since euhedral crystals can form in sub-solidus conditions as well as in the presence of a melt phase, and textural analysis in migmatites remains an uncertain science in which care must be exercised to distinguish textures related to melting from those produced by subsolidus processes alone (e.g. Dallain et al. 1999; Vernon 1999).

Figure 6 shows a hand sample of a stromatic migmatite in which smaller leucosomes appear to be crystallized from melt derived locally, whereas the larger leucosome on the left-hand side likely records evidence of melt moving through the 


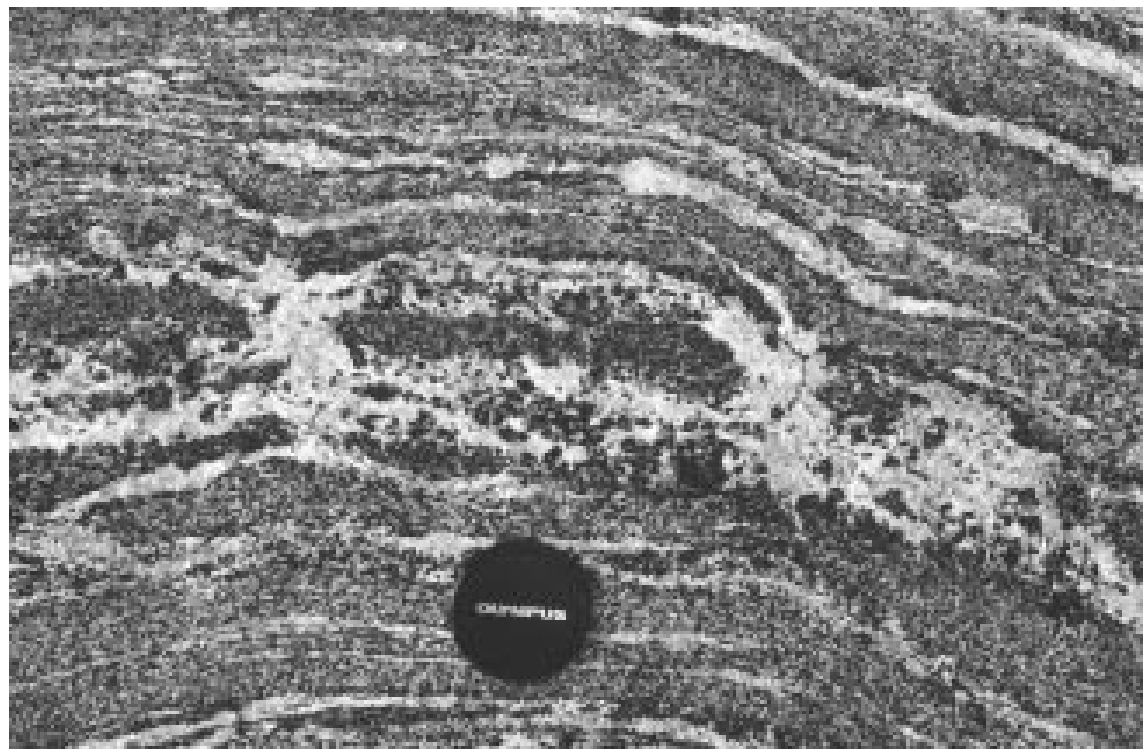

Figure 4. An example of leucosome accumulation in inter-boudin partitions, sites that are inferred to have been of lower pressure and in which melt therefore accumulated. Tolstik Peninsular, Karelia, Russia.

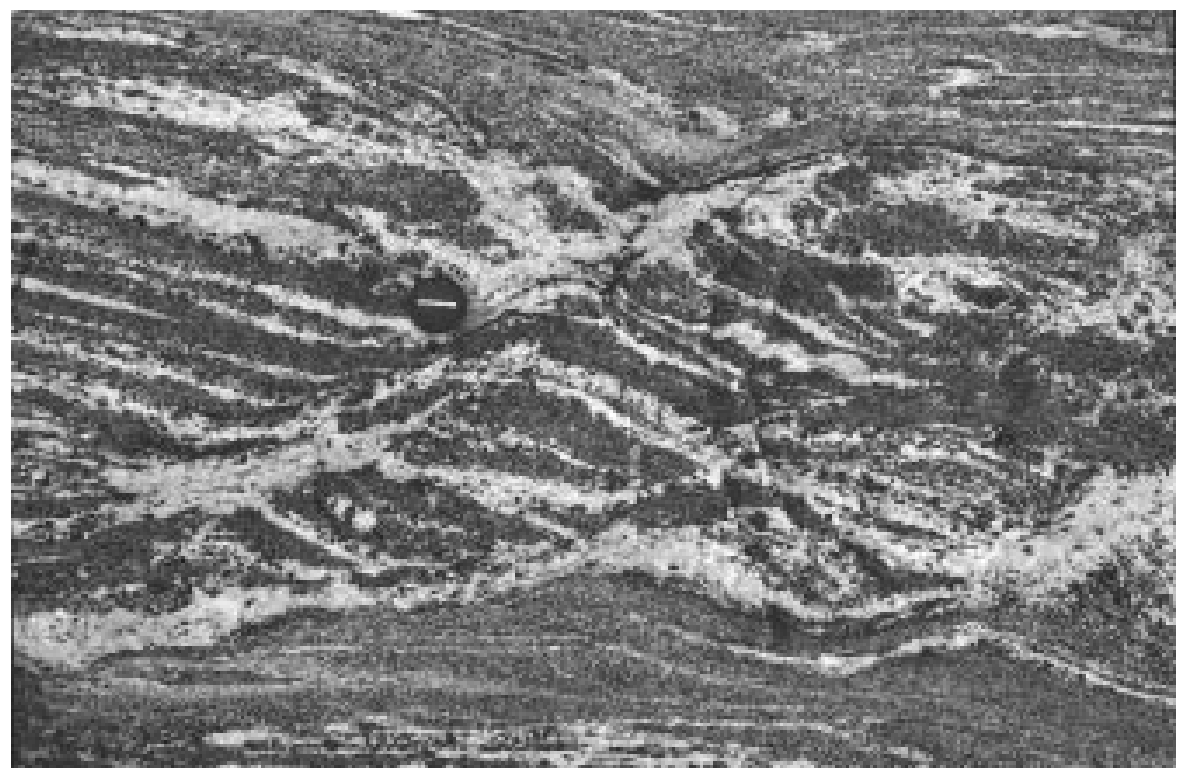

Figure 5. An example of leucosome accumulation in dilatant shear surfaces, sites that are inferred to have been of lower pressure and in which melt therefore accumulated. Tolstik Peninsular, Karelia, Russia.

system; a representative view of the microstructure of the larger leucosome is shown in figure 7 . Figure 8 shows contact migmatites from a middle crustal metamorphic aureole; the mesosome between the leucosome veins shows evidence of having been partially melted, such as the Kfeldspar patches shown in figure 9, although it is likely that the melt did not segregate into mesoscopic patches or veins.

Some migmatites exhibit evidence of meltenhanced embrittlement (e.g. Davidson et al. 1994) and leucosomes commonly show microstructures that suggest flow in the magmatic state (e.g. Blumenfeld and Bouchez 1988; Sawyer 1996; Brown and Solar 1998a, 1999). However, leucosome modes and/or chemical compositions commonly are interpreted to reflect dominance of cumulate and/or residual solid phases after melt escape, rather than melt compositions (e.g. Cuney and Barbey 1982; Powell and Downes 1990; Ellis and Obata 1992; Carson et al. 1997; Solar and Brown 2001b). Examples of deformed migmatite terrains in which the mineral assemblages and geochemical data suggest that melt loss has occurred are common (Weber et al. 1985; Powell and Downes 1990; Ellis and Obata 1992; Nyman et al. 1995; Hartel and Pattison 1996; Kriegsman 2001a, 2001b; Solar and Brown 2001b). In one example, Hartel and Pattison (1996) estimate 5-30 vol.\% melt loss from garnet amphibolites by comparison between observed 


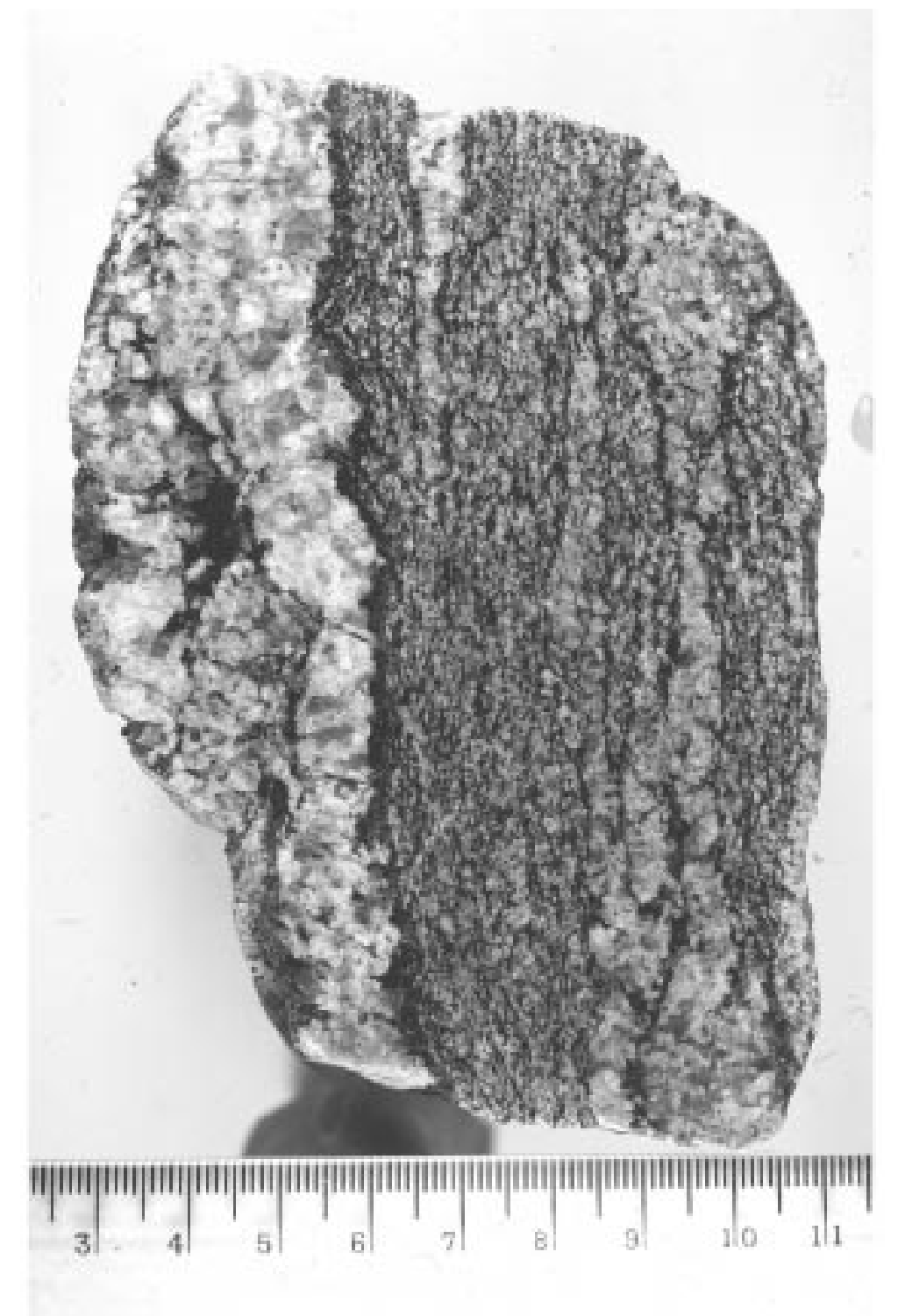

Figure 6. A hand sample of a stromatic migmatite in which smaller leucosomes on the right-hand side appear to be crystallized from melt derived locally, whereas the larger leucosome on the left hand side likely records evidence of melt moving through the system. Stromatic migmatite from South Brittany, France.

volume of leucosome and volume of melt expected based on mass balance calculations. This estimate is similar to those derived from experimental petrology for formation of tonalite-trondhjemitegranodiorite melts (e.g. Rapp and Watson 1995, 20-40 vol.\%) and those based on REE patterns of tonalite-trondhjemite-granodiorite suites in some Archean terranes (e.g. Luais and Hawkesworth $1994, \sim 25$ vol.\%). Thus, migmatitic garnet amphibolites may be representative of partially depleted source rocks for tonalite-trondhjemite-granodiorite suites. The critical point, however, is that although melt may have been lost from the system investigated by Hartel and Pattison (1996), not all of the melt generated was expelled; the partially depleted garnet amphibolites exhibit continuous concordant and discordant leucosomes that pre- serve the crustal plumbing that allowed melt loss to occur.

\section{Leucosome as evidence of a remnant permeability network}

Melt segregation, formation of permeability networks and melt extraction from crust in orogens occurs synchronously with deformation, as evidenced by field examples (Brown 1994; Brown and Rushmer 1997; Marchildon and Brown 2001). These processes have been investigated using analog models (Rosenberg and Handy 2000a, 2000b). The modeling emphasizes the importance of dilatant shear surfaces as sinks for melt and as important escape channels. It has been suggested (Brown and Solar 1998a, 1999; Brown et al. 1999) that 


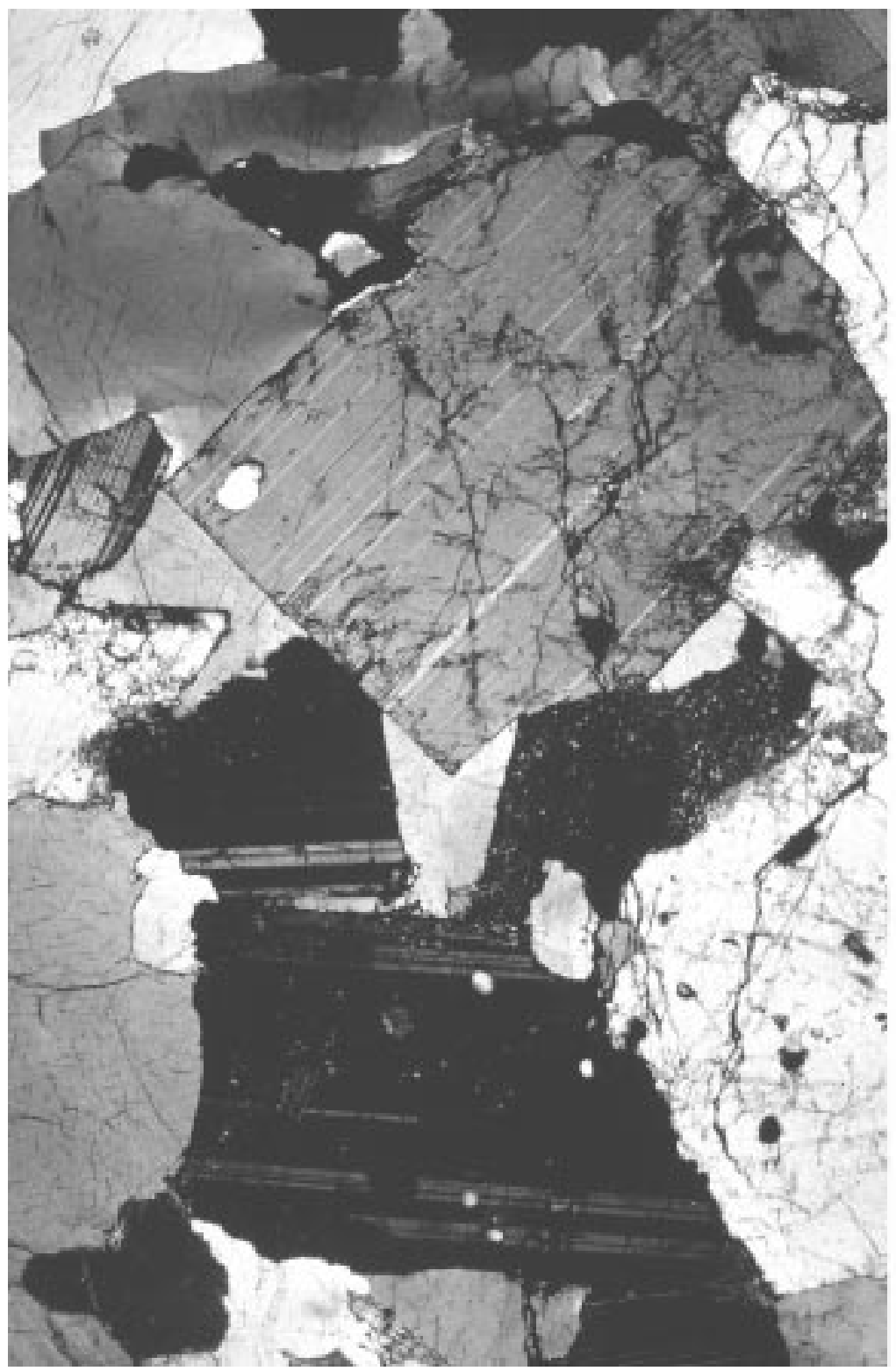

Figure 7. Microstructure of the larger leucosome shown in figure 6. Note the euhedral shape of the plagioclase phenocrysts against intersertal quartz.

melt migration pathways in migmatites relate to rock fabrics, although this may not be the case in all syntectonic vein networks (Handy et al. 2001). Some migmatites are depleted in a component equivalent to leucogranite, and these migmatite terrains may represent sources of leucogranite (Sawyer 1998; Milord et al. 2001; Solar and Brown 2001a).

In a recent study of the 3-dimensional topology of leucosome in a stromatic migmatite from the migmatitic core of the southern Brittany metamorphic belt (Brown M A et al. 1999), garnet crystals in leucosome are only locally in contact with the melanosome or mesosome; apparently they are never in contact with melanosome or mesosome on both sides of the leucosome. Jones and Brown (1990) suggested that one reaction respon- sible for the production of melt was $\mathrm{Bt}+\mathrm{Als}+$ $\mathrm{Qtz}(+\mathrm{Pl}) \rightarrow \mathrm{Grt} \pm \mathrm{Kfs}+\mathrm{L}$. The garnet observed in the leucosomes is likely to be the product of this moderate-to-low $a\left(\mathrm{H}_{2} \mathrm{O}\right)$, incongruent, biotitedehydration melt-producing reaction, which suggests that its present geometry represents suspension in melt. It could be argued that the planarity of the leucosomes is not a primary feature of the melt flow conduits but a secondary feature due to subsolidus deformation. This is unlikely to be the case because the microstructure of the leucosomes is largely magmatic, with some plagioclase crystals that have euhedral facies against quartz and some quartz that occurs as grain boundary films between plagioclase crystals; quartz shows only slight undulose extinction. Based on these observations, we infer that any post-crystalline defor- 


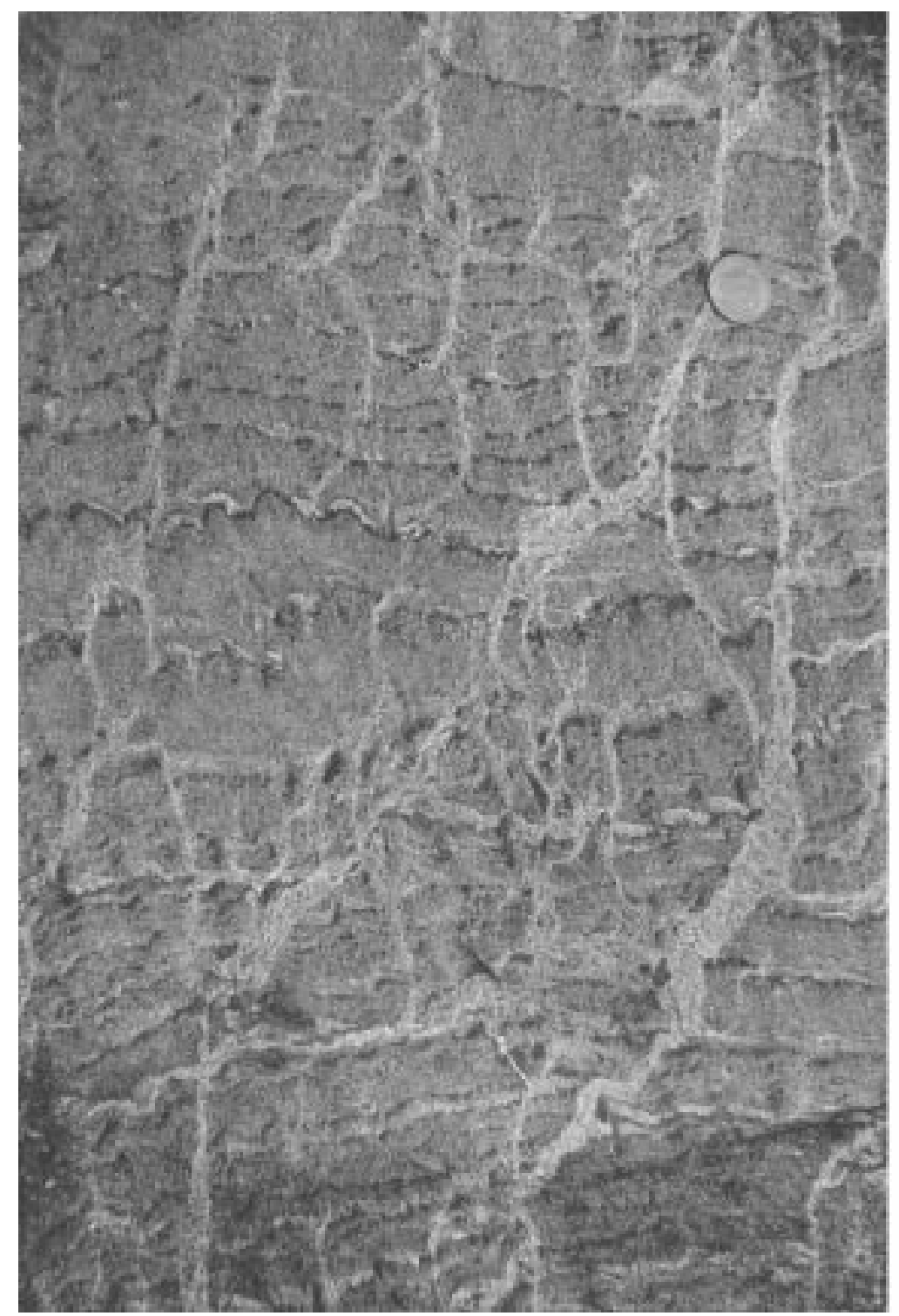

Figure 8. Contact migmatite from a middle crustal metamorphic aureole, Onawa, Maine. Note lit-par-lit leucosomes parallel to compositional layering and cross-cutting leucosomes discordant to composition layering.

mation has not modified the leucosome structure. However, there is no back-reaction between garnet and leucosome, which suggests that the leucosome composition does not represent the putative melt composition produced by the biotite dehydration melting reaction.

Based on the work of Brown M A et al. (1999), we may regard the leucosome retained in migmatites as recording the remnant permeability network, but how permeability networks evolve and how anomalies in permeability amplify during collisional orogenesis are poorly understood. However, for the specific case of crustal underplating by mafic melts, Petford and Koenders (1998b) have shown how isolated fractures that form during rapid thermal perturbation in a source can combine to form a single, interconnected structure with high permeability by self-organization.
Further, Miller and Nur (2000) have pointed out that local permeability can change instantaneously from one extreme to the other as a consequence of the fluid pressure evolution of the system leading to pore pressure increases sufficient to induce hydrofracture. Miller and Nur have used a cellular automaton model driven by an internal fluid source that incorporates a toggle-switch permeability to investigate how such a system self-organizes and develops to the critical state. Modeling ultimately will enable us to understand how permeability networks evolve (e.g. Petford and Koenders 1998b; and Miller and Nur 2000).

\section{Cyclic or continuous melt loss}

Most silicate melts wet the grain boundaries of the solid grains under static and dynamic condi- 


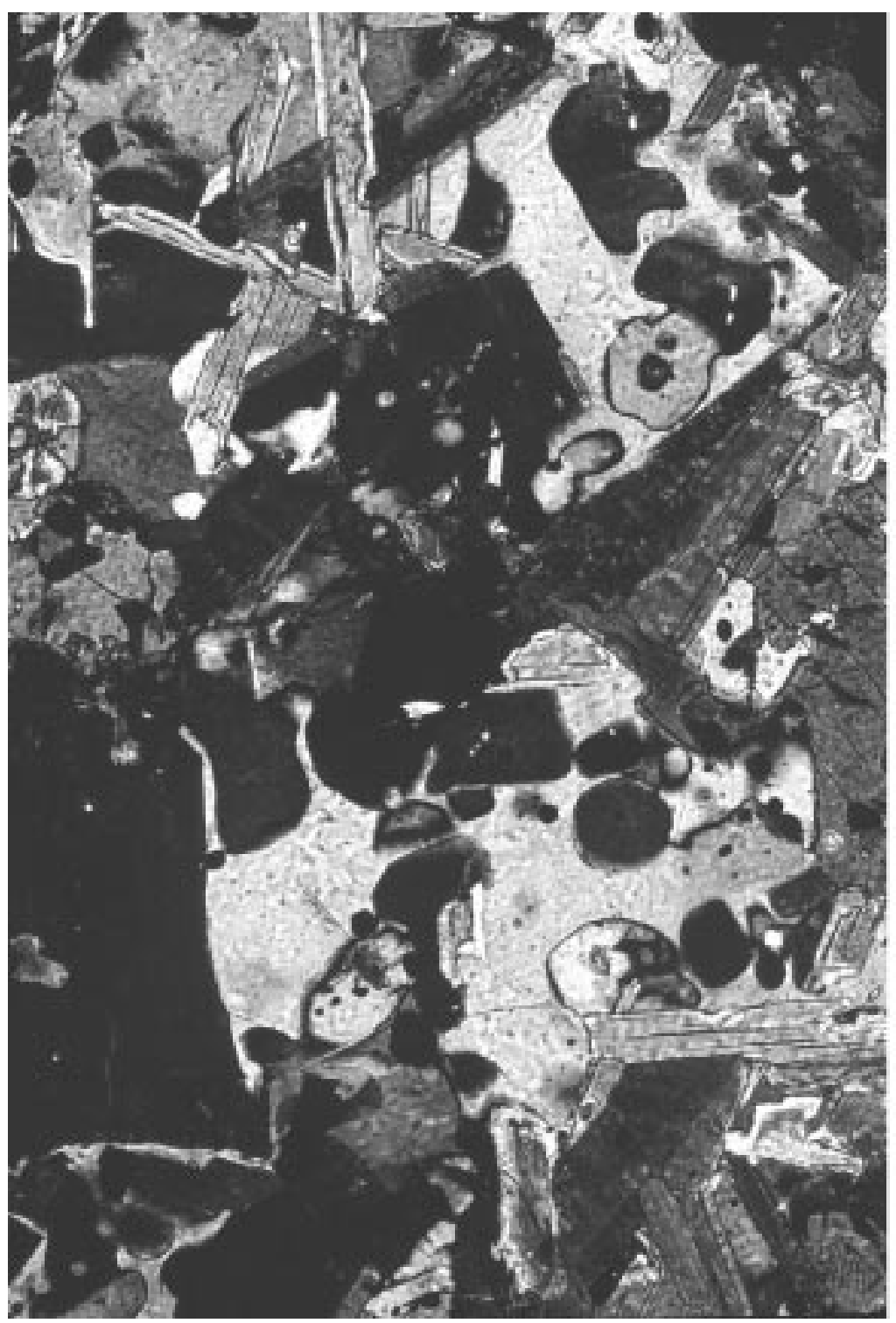

Figure 9. The mesosome between the leucosome veins in the migmatite of figure 8 shows evidence of having been partially melted, such as the K-feldspar patches (light gray) shown here, although the melt apparently did not segregate into mesoscopic patches or veins.

tions (Laporte et al. 1997; Brown and Rushmer 1997; Rosenberg and Riller 2000). Although the melt enhances diffusive mass transfer and accommodates granular flow of the solid grains (Paterson 2001), the melting rock initially behaves as a closed system and no melt is extracted. As melting progresses, during syntectonic anatexis, the protolith weakens and the solid material may deform by melt-assisted creep if the melt is retained. At an appropriate strain rate, at some strain determined by properties such as grain size, rate of melting and melt volume, buildup of melt pressure leads to formation of dilatant structures into which melt will flow down gradients in melt pressure (Brown and Rushmer 1997; Vanderhaeghe 1999). For example, nucleation of dilatant shear surfaces on melt pores localizes the strain, and these developing shear zones suck in melt from the surrounding matrix to further weaken the system. If such shear zones interconnect, then melt flows through the system, it becomes open and melt loss from the system causes strain hardening (Handy et al. 2001). This cycle of melt accumulation and melt loss repeats itself, and the system alternates between closed and open (Brown and Rushmer 1997; Brown and Solar 1999; Miller and Nur 2000).

In order to understand the migration of melt and the strength of partially molten rocks in orogens, it is necessary to understand the hydraulic transport properties of these materials and how those properties vary with space and time (e.g. Renner et al. 2000). Melt migration in the anatectic zone by pervasive flow (Weinberg 1999; Brown and Solar 1999; Leitch and Weinberg 2000) is not problem- 
atic, as Tanner (1999) has shown, although pervasive flow is limited by congelation when intruding cold country rock. At much lower strain rates, melt is extracted from the system fast enough that melt pressure does not build up sufficiently to allow magma fracture (Rutter 1997; Handy et al. 2001). Thus, low strain rates favor preservation of compositional layering, and dilatant structures, which fill with melt and disrupt layering, are unlikely to form. In this case, a melt-depleted granulite is the likely residue.

\section{The metamorphic volatile phase}

The presence or absence, nature and composition of the metamorphic volatile phase are important controls on what happens along both the prograde and retrograde portions of the $P-T$ path. Below the wet solidus, devolatilization reactions contribute products to a sporadic, spatially heterogeneous volatile phase. It is likely that the activities of components in the volatile phase are lithologically controlled, and flow either is lithologically or is structurally controlled. In contrast, a decrease in $a\left(\mathrm{H}_{2} \mathrm{O}\right)$, as well as an increase in $T$, and the onset of dehydration melting reactions characterize the transition from the amphibolite to the granulite facies. This precludes the general presence of a ubiquitous, pervasive metamorphic volatile phase (Yardley and Valley 1997), a conclusion that is supported by the $\mathrm{H}_{2} \mathrm{O}$-undersaturated nature of high- $T$ crustal melts (Clemens and Watkins 2001). The lowered $a\left(\mathrm{H}_{2} \mathrm{O}\right)$ could be achieved even in the presence of a metamorphic volatile phase as long as the quantity of this phase is limited, such that the system is rock-dominated rather than fluiddominated, or in the presence of an unlimited quantity of a volatile phase that is dominated by components other than $\mathrm{H}_{2} \mathrm{O}$, although both of these scenarios preclude melting. Melting is inferred to have occurred in most granulite facies terrains, whether the rocks have a migmatitic appearance or not (Brown 1994). Following this logic, Clemens and Watkins (2000) have argued that the correlation between melt $T$ and initial $\mathrm{H}_{2} \mathrm{O}$ content requires a rock-dominated, reaction buffered system. In this system, the volatile components are dissolved in the granite melt and transported with it to be exsolved upon crystallization. Thus, although segregation of melt from residue by distances greater than the equilibration volume may prevent back reaction from occurring, crystallization of the melt may promote retrogression in the surrounding host.

One feature common to many high-grade metamorphic terrains is the occurrence of leucosomes throughout the deformation history (e.g. Brown 1978; Fleming and White 1984; Jones and Brown
1990; Mogk 1990, 1992; Stevens and Van Reenen 1992; Brown and Dallmeyer 1996; Collins and Sawyer 1996). This ubiquitous association of anatectic leucosome with each phase of deformation may have implications concerning recycling $\mathrm{H}_{2} \mathrm{O}$ internally during orogenesis in a melting/movement/congelation positive feedback relation driven by deformation. Thus, melting may be initiated, for example by localization of deformation or migration of $\mathrm{H}_{2} \mathrm{O}$ into a shear zone, and dissolved $\mathrm{H}_{2} \mathrm{O}$ may migrate with the melt to be exsolved as the magma congeals in a structurally controlled site somewhere else. This exsolved $\mathrm{H}_{2} \mathrm{O}$ may initiate a new cycle of melt generation and migration, effectively recycling the $\mathrm{H}_{2} \mathrm{O}$, and the process may be repeated several times (e.g., Mogk 1990, 1992). Recycling of the metamorphic volatile phase in this manner has been suggested for several terrains, including the Thor-Odin metamorphic core complex of British Columbia (Holk and Taylor 1997), the Limpopo Belt of South Africa (Stevens 1997) and the Central Maine belt of New England, USA (Solar and Brown 2001b).

\section{Leucogranites in migmatite terrains}

If migmatites represent a crustal record of regional melting events, we must consider whether there is a relationship between migmatite leucosomes and residual host material, and granite plutons. Depending upon the composition of the protolith, whether there is any influx of a $\mathrm{H}_{2} \mathrm{O}$-rich metamorphic volatile phase, the rate of heating, the type of deformation and rate of strain and the maximum temperature achieved, as rocks cross the solidus they evolve sequentially from low melt fraction metatexites to high melt fraction diatexites, and to in situ granites if the melt is not extracted. Once the melt is extracted igneous processes may affect the magma leading to evolved granites typical of the upper crust. Factors that influence the composition of the melt include the composition of the source, the $P-T$ of melting and the meltproducing reaction, the distribution of accessory phases, whether they are on grain boundaries or within grains, and the lack of equilibrium during the melting process.

The occurrence of leucosome in metamorphic fabrics and in dilational sites within plastically deformed host rocks suggests it records syntectonic melt flow through deforming crust (Brown 1994; Brown and Rushmer 1997; Brown and Solar 1999), although leucosome compositions do not preserve melt compositions. Thus, leucosome in migmatite provides a record of the melt flow paths, and the leucosome structure in migmatite may provide a good analog for the melt flow network in the source 
(Brown M A et al. 1999), particularly if the process is scale invariant (Tanner 1999). In some cases, the form of magma ascent conduits apparently was deformation-controlled (Brown and Solar 1999), and was governed by the contemporaneous strainpartitioning characteristic of most orogens (Solar and Brown 2001a). Although migmatite terrains commonly have geochemical compositions consistent with melt loss (Brown et al. 1995a; Brown and Rushmer 1997; Solar and Brown 2001b), some schlieric migmatites reflect melt redistribution and accumulation (Sawyer 1996, 1998; Milord et al. 2001). Further, the cyclic behavior of melt segregation and escape leads to a pulsed flux of melt through and out of the anatectic zone (Brown and Solar 1999; Solar and Brown 2001b), consistent with the internal structure and geochemistry of many granite plutons (e.g. Brown et al. 1981; Brown and Pressley 1999; Pressley and Brown 1999).

Based on a variety of geochemical evidence, the leucosomes in many anatectic migmatites likely are the result of accumulation of crystals, both residual and newly crystallized (cumulate), during escape of residual melt (Marchildon and Brown 2001; Solar and Brown 2001a). As a direct complement, many large-volume upper-crustal leucogranites apparently represent evolved melt compositions. Thus, some migmatite terrains may represent pluton sources, and what we see at any particular crustal level depends on what gets stuck on its way through the system and how evolved this magma had become at the point of arrest (e.g. Sawyer 1998; Solar and Brown 2001b). What we do not see, however, are magma chambers in the source.

This process can be quantified by estimation of the volume of leucosome in residual migmatite terrains, knowledge of the bulk chemistry of the migmatites and the putative protolith, and estimation of the volume of evolved granite at shallower structural levels. For example, in the Acadian metamorphic belt of the northern Appalachians, comparison of the bulk chemical composition of the protolith metasedimentary rock succession and residual migmatites suggests an average melt loss of $\sim 20$ vol. \%. In these migmatites, leucosomes vary from probable melt compositions to compositions that imply a dominantly cumulate mineralogy, whereas small-volume granites vary from melt compositions to compositions that imply a cumulate mineralogy with entrained residue (Solar and Brown 2001a). Common leucogranites in one larger-volume granite studied in detail (Pressley and Brown 1999; Brown and Pressley 1999) have a range of compositions consistent with being derived by up to $\sim 20$ vol. $\%$ fractional crystallization of an anatectic melt derived from a source similar to the enclosing metasedimentary rocks. This suggests a relationship between crustal melting, leucosomes and smaller-volume granites that vary from melt to cumulate compositions, and largervolume granites that vary from primary to evolved melt compositions.

Based on the example above, I calculate that a pluton of volume $\sim 1750 \mathrm{~km}^{3}$ crystallized from a liquid with an evolved composition, derived by $\sim 20$ vol. $\%$ fractional crystallization of $\sim 20$ vol. $\%$ anatectic melt, requires a source volume of $\sim 11,000 \mathrm{~km}^{3}$. Put another way, a horizontal semi-circular half-cone-shaped pluton of diameter $\sim 30 \mathrm{~km}$ and half height $\sim 5 \mathrm{~km}$ (figure 10a) can be derived by $\sim 20 \mathrm{vol} . \%$ fractional crystallization of $\sim 20 \mathrm{vol} . \%$ anatectic melt segregated from a $\sim 15 \mathrm{~km}$ thick source of horizontal diameter $\sim 30 \mathrm{~km}$ (figure 10b). One implication of such a model, for the assumptions made, is that plutons derived in this manner might be spaced $\sim 30 \mathrm{~km}$ apart. A symmetric pluton (e.g. horizontal circular cone-shaped) of the same volume has a horizontal diameter of $\sim 21 \mathrm{~km}$, but requires the same source volume and spacing (figure 10b). For a pluton of four times greater volume (e.g. a horizontal tabular pluton of diameter $\sim 30 \mathrm{~km}$ and thickness $\sim 10 \mathrm{~km}$, figure $10(\mathrm{c})$, or horizontal circular coneshaped pluton with diameter $42 \mathrm{~km}$ and half height $\sim 5 \mathrm{~km}$ ), the horizontal diameter of the source, for the same assumptions, including a source thickness of $\sim 15 \mathrm{~km}$, becomes $\sim 60 \mathrm{~km}$ (figure $10 \mathrm{~d}$ ), which doubles the projected spacing of plutons. One implication of these geometric relationships between pluton and source is that flow through the storage porosity in the source is predominantly horizontal (or shallowly upward) rather than vertical, and flow is towards the ascent column, or radially to the center of the source for the simple cylinder geometry used above. A more sophisticated analysis of pluton-source shape and volume, and melt extraction and accommodation is given in Cruden and McCaffrey (2001).

\section{The switch from magma ascent to emplacement during orogeny}

In collisional orogens, although regional stress and buoyancy drive melt flow, ascent of magma commonly is controlled by the structures, particularly those that localize strain such as dilational shear zones. Melt flow networks require sustained transient near-lithostatic to supra-lithostatic melt pore pressure during deformation to prevent draw down, decreased transport rates and possible collapse. Assuming availability of melt in the storage porosity provided by the anatectic zone, limited by the granite wet solidus, and melt flow out of this source by pervasive and channeled mechanisms 


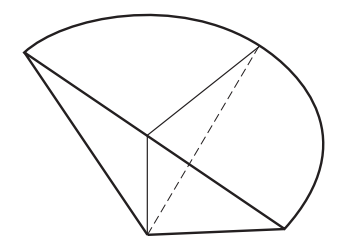

a.

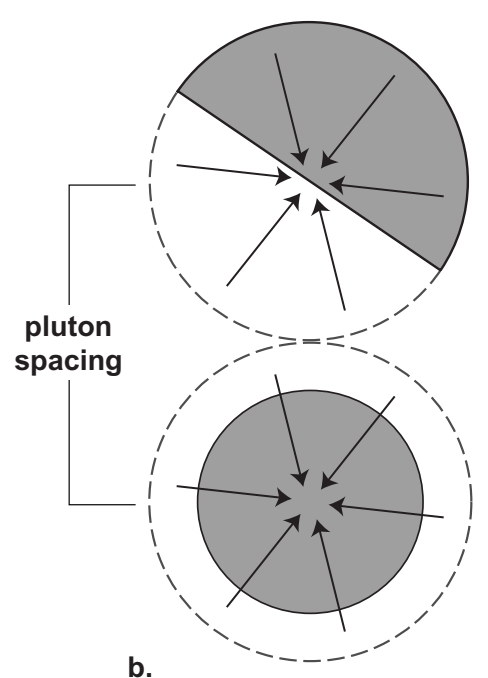

b.

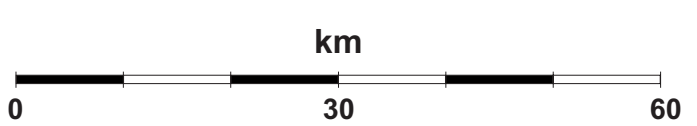

Figure 10. Pluton-source relations. (a) Perspective view of horizontal semi-circular half-cone-shaped pluton of diameter $\sim 30 \mathrm{~km}$ and half-height $\sim 5 \mathrm{~km}$. (b) Plan view of horizontal semi-circular half-cone-shaped pluton of diameter $\sim 30 \mathrm{~km}$ and horizontal circular cone-shaped pluton of diameter $\sim 21 \mathrm{~km}$ in relation to a source of sufficient volume to fill the pluton $(\sim 30 \mathrm{~km}$ diameter and $\sim 15 \mathrm{~km}$ thick). (c) Perspective view of horizontal tabular pluton of diameter $\sim 30 \mathrm{~km}$ and thickness $\sim 10 \mathrm{~km}$. (d) Plan view of horizontal tabular pluton of diameter $\sim 30 \mathrm{~km}$ in relation to a source of sufficient volume to fill the pluton (diameter $\sim 60 \mathrm{~km}$ and $\sim 15 \mathrm{~km}$ thick).

through an ascent column, we may ask: What controls the switch from magma ascent to emplacement, and how does this happen? To answer this we must realize the coupled nature of orogenic systems, with feedback relations among stress, deformation, thermal evolution, strength, strain rate, melt flow, etc. These systems are deterministic at large length scales, i.e., at the scale of the orogen itself, controlled by the external forces acting on them, but stochastic at small length scales, i.e., at the scale of part of the crust or the pluton, governed by the laws of probability. In such non-linear dynamical systems, large effects are generated from small fluctuations. The approach adopted here reconciles into one general model contradictory views put forth by proponents of the dike - horizontal tabular pluton, viscous flow in structurally-controlled channels - composite pluton with root and horizontal tabular head, and visco-elastic magmatic diapir ascent and emplacement models.
The perception that emplacement occurs at a 'level of neutral buoyancy' is inconsistent with the density of granite liquid $\left(\sim 2.44 \mathrm{~kg} \mathrm{~m}^{3}\right.$ at $1 \mathrm{GPa}$, $800^{\circ} \mathrm{C}$ ) and the range of emplacement depths. Further, the generalization that emplacement is controlled primarily by structural interactions between ascending melt and anisotropies in upper crust is only part of the story. Although plutons may be formed by magma expansion into an evolving structural trap (e.g. Hutton 1988; Grocott et al. 1994), or by multiple material transfer processes acting locally (Paterson and Fowler 1993; Paterson and Vernon 1995; Paterson et al. 1996), the systematic variation in 3 -D shape with depth, from horizontal tabular to blob-like to vertical lozenge, suggests that most emplacement occurs by two principal mechanisms, according to host rock behavior (a function of thermal gradient, strain rate, etc.). These are: in the brittle regime, by vertical inflation (lifting the roof/depressing the floor, accommodation mechanism(s) unspecified) after 
horizontal flow in a fracture or along a pre-existing anisotropy; and, in the viscous regime, by lateral expansion (swelling out like a balloon, accommodation mechanism(s) undefined) localized by some instability in the magma - wall-rock system.

In the brittle regime, magma may be arrested by a structure or 'crack stopper', some instability or thermal death (Clemens and Mawer 1992; Brown and Solar 1998b). Emplacement occurs when mainly vertical flow switches to predominantly horizontal flow. Analysis of the length vs. thickness of horizontal tabular plutons suggests they inflate according to a power law relationship, interpreted to mean that vertical thickening only occurs after magma has traveled horizontally some critical minimum distance (McCaffrey and Petford 1997; Cruden 1998; Petford et al. 2000). Depression of the floor and/or lifting of the roof allow inflation to be assimilated (Cruden 1998; Brown and Solar 1998b). Although sagging of the floor can be accommodated because magma has been extracted at depth, no simple relationship exists since the volume of melt in the pluton is from a much larger source volume (although see Cruden 1998; Cruden and McCaffrey 2001). To lift the roof, $P_{\text {melt }}$ must overcome lithostatic load and tectonic overpressure.

In the viscous regime, amplification of naturally occurring instabilities in the system likely causes the switch from ascent to emplacement. Instabilities may be internal to the ascent column, such as fluctuations in permeability or magma flow rate (or changes in cross-sectional shape), or external to the ascent column, such as variations in strength or state of stress in the host rock. These instabilities are not mutually exclusive, and feedback relations are likely to produce similar results whatever the initial instability. Consider an ascent column with zones of higher permeability; these will be conduits of higher magma flux. However, higher flux may lead to increased permeability, and increased heating and consequent weakening of the host rock surrounding these conduits, which in turn increases the strain rate; all of these interactions lead to even higher magma flux, and so on. If a feedback relation of this kind indeed exists in nature, it may lead to concentration of magma flow into a small number of larger ascent conduits. Magma in the preferred ascent conduits will exploit the weakening and may expand into the host rock, switching ascent to emplacement and forming a vertical lozenge pluton. The 'diapiric' intrusions of Miller and Paterson (1999) may have been emplaced by such a mechanism. A similar phenomenon occurs if the instability is due to differences in the strength of the host rock or the stress field around the ascent column. Magma exploits the weaker/lower stress sectors, swelling or intruding out of the ascent column into those sites (accommodation mechanism(s) will vary from the viscous to the brittle regime), heating and weakening the host rocks, which enables further lateral expansion, forming a blob-like pluton. The nested 'diapirs' of Paterson and Vernon (1995) may have been emplaced by such a mechanism.

Above the anatectic zone, differences in flow rate or cross-sectional shape of the ascent conduit may lead to fluctuations around the critical width for flow without freezing. If freezing occurs in the slower/narrower parts of the conduit, flow will focus in the faster/wider parts. Heating of the host rock is likely to cause weakening that will facilitate swelling of the conduit. In the upper crust, at high-strains, rock strength below the initial brittleto-viscous transition depth-interval may decrease to less than that of the over- and underlying crust (Handy 1989; Handy et al. 2001). This strain weakening is attributed to transitions from cataclasis (just above the initial brittle to viscous transition) or grain-size insensitive (dislocation) creep (just below the initial brittle-to-viscous transition) to grain-size sensitive creep (diffusion creep, diffusionor reaction-accommodated granular flow) in finegrained, polymineralic aggregates (Handy 1989; Handy et al. 2001). This strain-dependent strength minimum just below the brittle-to-viscous transition has important implications for arresting the ascent of magma and enabling lateral emplacement (Handy et al. 2001). At this crustal level, the switch to emplacement may lead to formation of a pluton with a horizontal tabular head, formed by inflation of a sub-horizontal magma fracture, and a hemi-ellipsoidal root that passes down into a migmatite zone through which magma was transferred (Brown and Solar 1999). In such a composite pluton, the hemi-ellipsoidal root is thought to have formed by back filling and freezing as the thermal structure decayed due to declining magma flow rate. The decline in magma flow rate could be a consequence of the 'end' of magma emplacement or the 'end' of melt extraction. In effect, the rate of magma inflow to the pluton is insufficient to maintain continued inflation and the resultant feedback ultimately terminated magma ascent and extraction from the source. This is consistent with the expected decline in extraction rate with time from a finite volume source.

\section{Rates of processes}

We may separate the processes of melt generation and melt segregation, and magma extraction, ascent and emplacement. However, this is not meant to imply a simple succession of events, and in any case feedback relations are expected 
among these processes and with the applied differential stress. For example, in principle, the relative rates of melt generation and segregation will determine whether the melt is able to separate from the residue above some percolation threshold. However, in collision zones these processes are associated with deformation, and the rate of melt pressure buildup may determine by what mechanism and at what rate the melt segregates. Further, we may consider the relative rates of melt segregation and extraction to be the control on whether migmatites or depleted granulites form, or whether sufficient melt escapes to form plutonic bodies of granite. However, the cumulate mineralogy of many migmatite leucosomes suggests that crystallization will begin before melt escape from the anatectic zone is achieved. Also, the rates of melt segregation and extraction will be influenced by the rates of melt generation and magma ascent. There is a feedback relation between the rate of magma emplacement and the rate of ascent, with fast ascent potentially driving fast birth and inflation of plutons (McCaffrey and Petford 1997; Cruden 1998). Conversely, at the limit of maximum pluton inflation, i.e. when the pluton cannot grow further for whatever reason, feedback must slow down the ascent rate. The rate-limiting step in pluton formation is unlikely to be emplacement rate, ascent rate or even extraction rate, but is most likely to be related to the rates of generation and segregation, which will be controlled by the thermal evolution and the deformation.

What are these rates (see also Thompson 1999)? Based on detailed regional studies of crystallization ages in migmatites and granites, we know that the whole process, from the peak of metamorphism to pluton emplacement, can be accomplished on a time scale of less than $1 \mathrm{Ma}$ (e.g. Solar et al. 1998). The rate of melt generation will be limited by heat flow, but heat flow is only likely to be a rate-limiting step at short time scales (Rutter 1997). Further, calculation of volume change associated with melting in experiments on muscovite-, muscovite + biotite-, and biotite-bearing rocks suggests that muscovite-bearing assemblages, with or without biotite, have a high enough positive volume change to enable magma fracture, whereas biotite-bearing assemblages have negligible volume change (Rushmer 2001). Muscovite dehydration melting reactions occur over a narrow temperature range. In the experiments on protolith schists from the Himalayas, Patiño Douce and Harris (1998) suggest that $\sim 20$ vol. $\%$ melt is generated within $25^{\circ} \mathrm{C}$ rise in $T$ above the solidus, with a higher vol.\% melt generated if $\mathrm{H}_{2} \mathrm{O}$ is added to the system. This estimate is consistent with estimates of melt loss based on the depletion in some migmatite terrains (e.g. Solar and
Brown 2001b). Muscovite dehydration melting produces a significant pulse of melt that will increase melt pore pressure rapidly. Thus, lower temperature crustal melting involving muscovite dehydration may be associated with fast melt segregation and magma extraction, whereas higher temperature crustal melting involving biotite dehydration may lead to melt retention at lower vol.\%, unless deformation increases the rate of melt pore pressure buildup (cf. Rushmer 2001).

There are many variables that contribute to an evaluation of the rate of segregation of melt from partially-molten crust (Rutter 1997), including protolith grain size, $\mathrm{H}_{2} \mathrm{O}$ content and applied differential stress. At lower differential stresses and higher $T$, shear-enhanced compaction dominates the segregation process, whereas at higher differential stresses and lower $T$, extraction occurs more efficiently via vein networks. Nonetheless, to extract melt in a geologically reasonable timescale a combination of grain-scale flow, driven by gradients in melt pressure, to veins and flow through veins, driven by buoyancy forces, is required. For an appropriate grain size $(5 \mathrm{~mm})$, segregation of 10 vol.\% melt from a segment of crust by porous flow to veins by shear-enhanced compaction and flow of melt through veins likely takes place on the order of $10^{3}-10^{5}$ years, implying bulk strain rates in the range $10^{-12}-10^{-14} \mathrm{~s}^{-1}$. This estimate is consistent with timescales of $<10^{3}$ based on accessory phase dissolution (Harris et al. 2000).

Once melt is segregated into veins it represents a source to support extraction. The rate of melt extraction potentially may be significantly faster that segregation, supported by the melt stored in veins, particularly if migmatites have a fractal structure similar to the example studied by Tanner (1999). In this example, the vein network has a fractal dimension similar to the Menger Sponge. In a Menger Sponge, melt must travel a distance twice the width of the vein to reach a vein of three times the size. For an initial vein of several centimeters width and an appropriate melt viscosity, it is clear that melt accelerates through the anatectic zone as increasing channel widths allow faster rate of flow. The Menger Sponge model is an ana$\log$ to the pervasive flow mechanism of Brown and Solar (1999), Vanderhaeghe (1999) and Weinberg (1999).

There are many variables also that control the rate of ascent. Typical ascent rates for crystalfree magma in a dike of several meters width are on the order of $0.1 \mathrm{~m} \mathrm{~s}^{-2}$ (Clemens 1998), which means that a pluton of volume $\sim 1,000 \mathrm{~km}^{3}$ can be filled in a time as short as $\sim 1,000$ years (if both the extraction rate and the inflation rate can keep pace). Cruden (1998) estimates that a $\sim 3 \mathrm{~km}$ thick horizontal tabular pluton of diameter 
$10-100 \mathrm{~km}$ will fill on a time scale of 100 years to 1 million years, with an average host strain rate to accommodate the emplacement in the range $10^{-10}$ $-10^{-15} \mathrm{~s}^{-1}$ (see also Petford et al. 2000; Cruden and McCaffrey 2001). Harris et al. (2000) argue that melt ascent will be extremely fast, occurring on a timescale possibly as short as $\sim 10 \mathrm{yr}$. According to Clemens (1998), such a $\sim 3 \mathrm{~km}$ thick pluton in the upper crust will cool below the solidus at its center in a time of $\sim 30,000$ years.

What are the implications of fast timescales for melt segregation, and magma extraction, ascent and emplacement? First, the overall ratedetermining step in crustal melting and the formation of granite plutons will be heat flow. Second, the rapid timescales imply that this equilibrium between granite magma and its source will be preserved (e.g. Hammouda et al. 1996; Davies and Tommasini 2000) and reflected in the heterogeneous isotope compositions of plutons (e.g. Deniel et al. 1987; Pressley and Brown 1999). It follows, that one popular assumption underlying many geochemical studies of granites, that the magmas image the source region, may not be reasonable.

\section{Conclusions}

Granite magmatism represents a major crustal recycling mechanism in orogens and the principal mechanism by which the geochemical differentiation of Earth's crust has happened since the Archaean. The intimate link between orogeny and crustal melting requires an interdisciplinary approach in which field observations, experimental investigations and theory from diverse disciplines including geophysics, geochemistry, petrology, tectonics and modeling contribute. This interdisciplinary research in orogenesis and crustal melting is leading to significant advances in understanding.

Examples of such advances are:

- The improvement in geophysical techniques and the development of the petrophysical basis for the interpretation of geophysical data, which have enabled us to infer the presence of melt in the middle crust of active orogens and to place limits on the amount of melt present in the crust.

- The revelation that melt generation and segregation, and magma extraction, ascent and emplacement generally are syntectonic processes involving feedback relations, and that rates and timescales likely are much shorter than once believed.

- A better understanding of the feedback relations among the various processes involved, particularly the thermal structure and deformation. Compatibility is maintained by these feedback relations, exemplified by the fact that rates of melt segregation fall within the range of strain rates for host rocks to accommodate pluton emplacement.

- The use of more sophisticated analog and numerical models in understanding the interrelationships between deformation and melt migration.

- Understanding the switch from ascent to emplacement as a process controlled by various interrelated factors, but in which the style of this switch and the accommodation mechanisms of emplacement relate to the depth of the viscousto-brittle transition in the crust.

- A better understanding of the rheology of partially molten crust, and its role in orogenic collapse.

- The use of geochemistry as a discriminator between competing hypotheses; for example, concerning whether or not there is a relationship between migmatites and granites.

\section{Acknowledgements}

Discussion with many people, most recently Sandy Cruden, Nick Petford, Ed Sawyer, Gary Solar and Roberto Weinberg; my ideas are irretrievably entangled with theirs, but any mistakes most likely are mine! I thank Gary Solar for drafting figure 1 and Nathalie Marchildon for drafting figure 10.

\section{References}

Alsdorf D and Nelson D 1999 Tibetan satellite magnetic low: Evidence for widespread melt in the Tibetan crust?; Geology, 27 943-946

Alsdorf D and 5 others, 1998 Crustal deformation of the Lhasa Terrane, Tibet Plateau from Project INDEPTH Deep Seismic Reflection Profiles; Tectonics, 17 501-519

Ashworth J R (ed) 1985 Migmatites. Glasgow: Blackie.

Ashworth J R and Brown M 1990 High-temperature Metamorphism and Crustal Anatexis. The Mineralogical Society Series: 2 London: Unwin Hyman.

Atherton M P and Tarney J 1979 Origin of granite batholiths. (Shiva Publishing Ltd.)

Baldwin S L, Lister G S, Hill E J, Foster D A and McDougall I 1993 Thermochronologic constraints on the tectonic evolution of active metamorphic core complexes, D'Entrecasteaux Islands, Papua New Guinea; Tectonics, 12 611-628

Barboza S A, Bergantz G W and Brown M 1999 Regional granulite facies metamorphism in the Ivrea zone: Is the Mafic Complex the smoking gun or a red herring? Geology, 27 447-450

Barr T D and Dahlen F A 1989 Brittle frictional mountain building 2. Thermal structure and heat budget; J. Geophys. Res., 94 3923-3947

Barton M D and Hanson R B 1989 Magmatism and development of low pressure metamorphic belts - implications from the western-United States and thermal modeling; Geol. Soc. Am. Bull., 101 1051-1065 
Benn K, Odonne F and de Saint Blanquat M 1998 Pluton emplacement during transpression in brittle crust: new views from analogue experiments; Geology, 26 10791082

Blumenfeld P and Bouchez J L 1988 Shear criteria in granite and migmatite deformed in the magmatic and solid states; J. Struct. Geol., 10 361-372

Braun I and Kriegsman L M 2001 Partial melting in crustal xenoliths and anatectic migmatites: a comparison; Phys. Chem. of the Earth, (A) $\mathbf{2 6} 261-266$

Brown M 1973 The Definition of Metatexis, Diatexis and Migmatite; Proc. Geol. Assoc. 84 371-382

Brown M 1978 The tectonic evolution of the Precambrian rocks of the St. Malo region, Armorican Massif, France; Precambrian Res. 6 1-21

Brown M 1993 P-T-t evolution of orogenic belts and the causes of regional metamorphism; J. Geol. Soc., London $150227-241$

Brown M 1994 The generation, segregation, ascent and emplacement of granite magma: The migmatite-tocrustally-derived granite connection in thickened orogens; Earth-Sci. Rev. 36 83-130

Brown M 1997 Migmatites and Melt Migration. In: Precambrian Geology and Metamorphic Petrology, (eds.) Q Xianglin, Y Zhendong, and H C Hall. Proceedings of the 30th International Geological Congress, VSP, Zeist, The Netherlands, pp. 187-202

Brown M 1998 Unpairing metamorphic belts: P-T paths and a tectonic model for the Ryoke Belt, southwest Japan; $J$. metamorphic Geol., 16 3-22

Brown M 2001 From microscope to mountain belt. 150 years of petrology and its contribution to understanding the tectonics of orogens; J. Geodynamics, 32 115-164

Brown M and Dallmeyer R D 1996 Rapid Variscan exhumation and role of magma in core complex formation: Southern Brittany metamorphic belt, France; J. metamorphic Geol., 14 361-379

Brown M and D'Lemos R S 1991 The Cadomian granites of Mancellia, north-east Armorican Massif of France: relationship to the St. Malo migmatite belt, petrogenesis and tectonic setting. Precambrian Research, 51 393-427

Brown M and O'Brien P J 1997 Evolution of Metamorphic Belts: A Changing View. In: Precambrian Geology and Metamorphic Petrology, (eds.) Q Xianglin Y Zhendong and $\mathrm{H} \mathrm{C}$ Hall. Proceedings of the 30th International Geological Congress, VSP, Zeist, The Netherlands, pp. 217231

Brown M and Pressley R A 1999 Crustal melting in nature: Prosecuting source processes; Phys. Chem. of the Earth, (A) 24 305-316

Brown M and Raith M 1996 First evidence of ultra hightemperature decompression from the granulite province of Southern India; J. Geol. Soc., London 153 819-822

Brown M and Rushmer T 1997 The role of deformation in the movement of granite melt: views from the laboratory and the field. In: Deformation-enhanced Fluid Transport in the Earth's Crust and Mantle (ed.) M B Holness. The Mineralogical Society Series 8 Chapman and Hall, London, pp. 111-144

Brown M and Solar G S 1998a Shear zone systems and melts: Feedback relations and self-organization in orogenic belts; J. Struct. Geol., 20 211-227

Brown M and Solar G S 1998b Granite ascent and emplacement during contractional deformation in convergent orogens; J. Struct. Geol., 20 1365-1393

Brown M and Solar G S 1999 The mechanism of ascent and emplacement of granite magma during transpression: a syntectonic granite paradigm; Tectonophysics, 312 133
Brown M, Friend C R L, McGregor V R and Perkins W T 1981 The late-Archaean Qôrqut granite complex of southern West Greenland; J. Geophys. Res., 86 10,617-10,632

Brown M, Rushmer T and Sawyer E W 1995a Introduction to Special Section: Mechanisms and consequences of melt segregation from crustal protoliths; J. Geophys. Res., 100 15,551-15,563

Brown M, Averkin Y, McLellan E and Sawyer E 1995b. Melt segregation in migmatites; J. Geophys. Res., 100 15,65515,679

Brown M A, Brown M, Carlson W D and Denison C 1999 Topology of syntectonic melt flow networks in the deep crust: inferences from three-dimensional images of leucosome geometry in migmatites; Amer. Mineral., 84 17931818

Brun J P and Cobbold P R 1980 Strain heating and thermal softening in continental shear zones: a review; J. Struct. Geol., 2 149-158

Brun J P, Gapaas D, Cogne J P, Ledru P and Vigneresse J L 1990 The Flamanville granite (northwest France) an unequivocal example of a syntectonically expanding pluton; Geol. J., 25 271-286

Burg J P, Van Dendriessche J and Brun J P 1994 Syn-to post-thickening extension in the Variscan Belt of western Europe: Mode and structural consequences; Geol. de la France, 3 33-51

Burnham C W 1979 Magmas and hydrothermal fluids. In: (ed.) Geochemistry of Hydrothermal Ore Deposits, 2nd Edition, H L Barnes, New York: Wylie-Interscience, pp. $71-136$

Carson C J, Powell R, Wilson C J L and Dirks P H H M 1997 Partial melting during tectonic exhumation of a granulite terrane: an example from the Larsemann Hills, East Antarctica; J. metamorphic Geol., 15 105126

Castro A, Corretga L G, El-Biad M, El-Hmidi H, Fernandez C and Patino Douce A E 2000 Experimental constraints on Hercynian anatexis in the Iberian Massif, Spain. J. Petrol., 41 1471-1488

Cesare B, Salvioli Mariani E and Venturelli G 1997. Crustal anatexis and melt segregation in the restitic xenoliths of El Hoyazo (SE Spain). Min. Mag., 61 15-27

Chamberlain C P and Sonder L J 1990 Heat-producing elements and the thermal and basic patterns of metamorphic belts; Science, 250 763-769

Clemens J D 1998 Observations on the orogens and ascent mechanisms of granitic magmas; J. Geol. Soc., London, $155843-851$

Clemens J D and Mawer C K 1992 Granitic magma transport by fracture propagation; Tectonophysics, 204339 360

Clemens J D and Watkins J M 2001 The fluid regime of hightemperature metamorphism during granitoid magma genesis; Contrib. Mineral. Petrol., 140 600-606

Collins W J and Sawyer E W 1996 Pervasive magma transfer through the lower-middle crust during non-coaxial compressional deformation: An alternative to diking; J. metamorphic Geol., 14 565-579

Connolly J A D, Holness M B, Rushmer T and Rubie D C 1997 Reaction-induced microcracking: An experimental investigation of a mechanism for enhancing anatectic melt extraction; Geology, 25

Connolly P and Cosgrove J 1999 Prediction of fractureinduced permeability and fluid flow in the crust using experimental stress data. AAPG Bull., 83 757-777

Cruden A R 1998 On the emplacement of tabular granites; J. Geol. Soc. London, $155853-862$

Cruden A R and McCaffrey K J W 2001 Growth of plutons by floor subsidence: implications for rates of emplace- 
ment, intrusion spacing and melt-extraction mechanisms; Phys. Chem. of the Earth, 26 303-315

Cuney M and Barbey P 1982 Mise en evidence de phenomanes de cristallisation fractionnée dans les migmatites. C.R. Acad. Sc. Paris, 295 37-42

Dallain C, Schulmann K and Ledru P 1999 Textural evolution in the transition from subsolidus annealing to melting process, Velay Dome, French Massif Central; J. metamorphic Geol., 17 61-74

Davidson C, Schmid S M and Hollister L S 1994 Role of melt during deformation in the deep crust; TERRA Nova, 6 133-142

Davis G R and Tommasini S 2000 Isotopic disequilibrium during rapid crustal anatexis: implications for petrogenetic studies of magmatic processes; Chem. Geol., 162 169-191

Davis J H and von Blanckenburg F 1995 Slab breakoff: A model of lithosphere detachment and its test in the magmatism and deformation of collisional orogens; Earth Planet. Sci. Lett., 129 85-102

Del Moro A, Martin S and Prosser G 1999 Migmatites of the Ulten Zone (NE Italy), A record of melt transfer in deep crust; J. Petrol., 40 1803-1826

Deniel C, Vidal P, Fernandez A, LeFort P and Peucat J J 1987 Isotopic study of the Manaslu Granite (Himalaya, Nepal) - inferences on the age and source of Himalayan leucogranites; Contrib. Mineral. Petrol., 96 78-92

Dewey J F 1988 Extensional collapse of orogens; Tectonics, 7 1123-1139

DeYoreo J J, Lux D R, Guidotti C V, Decker E R and Osberg P H 1989 The Acadian thermal history of western Maine; J. metamorphic Geol., 7 169-190

DeYoreo J J, Lux D R and Guidotti C V 1991 Thermal modelling in low-pressure/high-temperature metamorphic belts; Tectonophysics, 188 209-238

Dougan T W 1979 Compositional and modal relationships and melting relationships in some migmatitic metapelites from New Hampshire and Maine; Amer. J. Sci., 279 897935

Dougan T W 1981 Melting reactions and trace element relationships in selected specimens of migmatitic pelites from New Hampshire and Maine; Contrib. Mineral. Petrol., 78 337-344

Ellis S and Beaumont C 1999 Models of convergent boundary tectonics: Implications for the interpretation of Lithoprobe data; Can. J. Earth Sci., 36 1711-1741

Ellis D J and Obata M 1992 Migmatite and melt segregation at Cooma, New South Wales; Trans. R. Soc., Edinburgh, Earth Sci., 83 95-106

Fleitout L and Froidevaux C 1980 Thermal and mechanical evolution of shear zones; J. Struct. Geol., 2 159-164

Fleming P D and White A J R 1984 Relationships between deformation and partial melting in the Palmer migmatites; Austral. J. Earth Sci., 31 351-360

Franz L and Harlov D E 1998 High-grade K-feldspar veining in granulites from the Ivrea-Verbano zone, northern Italy: Fluid flow in the lower crust and implications for granulite facies genesis; J. Geol., 106 455-472

Gerdes A, Worner G and Henk A 2000 Post-collisional granite generation and HT-LP metamorphism by radiogenic heating: the Variscan South Bohemian Batholith; J. Geol. Soc., London, 157 577-587

Grocott J, Brown M, Dallmeyer R D, Taylor G K and Treloar P J 1994 Mechanisms of continental growth in extensional arcs: An example from the Andean plate boundary zone; Geology, 22 391-394

Hammouda T, Pichavant M and Chaussidon M 1996 Isotopic equilibration during partial melting: an experimen- tal test of the behavior of Sr. Earth and Planet Sci. Let., $144109-121$

Handy M R 1989 Deformation regimes and the rheological evolution of fault zones in the lithosphere: the effects of pressure, temperature, grainsize and time; Tectonophysics, 163 119-152

Handy M R, Franz L, Heller F, Janott B and Zurbriggen R 1999 Multistage accretion and exhumation of the continental crust (Ivrea crustal section, Italy and Switzerland); Tectonics, 18 1154-1177

Handy M R, Mulch A, Rosenau M and Rosenberg C L 2001 The role of fault zones and melts as agents of weakening, hardening and differentiation of the continental crust: a synthesis, In: The nature and tectonic significance of fault zone weakening (eds.) R E Holdsworth, J Magloughlin, R J Knipe, R A Strachan and R C Searle, Geol. Soc. Spec. Publ., 186 305-332

Harlov D E, Hansen E C and Bigler C 1998 Petrologic evidence for $\mathrm{K}$-feldspar metasomatism in granulite facies rocks; Chem. Geol., 151 373-386

Harmon R S and Rapela C W 1992 Andean magmatism and its tectonic setting Geol. Soc. Amer., Spec. Paper, 265 pp. 309

Harris N, Vance D and Ayres M 2000 From sediment to granite: timescales of anatexis in the upper crust; Chem. Geol., 162 155-167

Harrison T M, Lovera O M and Grove M 1997 New insights into the origin of two contrasting Himalayan granite belts; Geology, 25 899-902

Harrison T M, Grove M, Lovera O M and Katlos E J 1998 A model for the origin of Himalayan anatexis and inverted metamorphism; J. Geophys. Res., 103 27017-27032

Harte B, Pattison D R M and Linklater C M 1991 Field relations and petrography of partially melted pelitic and semi-pelitic rocks. In: Equilibrium and kinetics in contact metamorphism: The Ballachulish igneous complex and its aureole (eds.) G Voll, J Töpel, D R M Pattison and F Seifert. Springer-Verlag, Berlin and Heidelberg, pp. 82210

Hartel T H D and Pattison D R M 1996 Genesis of the Kapuskasing (Ontario) migmatitic mafic granulites by dehydration melting of amphibole: The importance of quartz to reaction progress; J. metamorphic Geol., 14 591-611

Haugerud R and Zen E-an 1991 An essay on metamorphic path studies or Cassandra in P-T-t space. (ed.) L L Perchuk. Progress in metamorphic and magmatic petrology, Cambridge, U K: Cambridge University Press, pp. 323348

Hodges K V 1998 The thermodynamics of Himalayan orogenesis; Geol. Soc. Spec. Publ., 138 7-22

Hodges K V 2000 Tectonics of the Himilaya and southern Tibet from two perspectives; Geol. Soc. Amer. Bull., 112 $324-350$

Holk G J and Taylor H P Jr. $1997{ }^{18} \mathrm{O} /{ }^{16} \mathrm{O}$ homogenization of the middle crust during anatexis: the Thor-Odin metamorphic core complex, British Columbia; Geology, 25 31-24

Hollister L S 1993 The role of melt in the uplift and exhumation of orogenic belts; Chem. Geol., 108 31-48

Holness M B and Clemens J D 1999 Partial melting of the Appin Quartzite driven by fracture-controlled $\mathrm{H}_{2} \mathrm{O}$ infiltration in the aureole of the Ballachulish Igneous Complex, Scottish Highlands; Contrib. Mineral. Petrol., 136 154-168

Huang W L, Wyllie P J 1981 Phase relationship of S-type granite with $\mathrm{H}_{2} \mathrm{O}$ to 35 kbar: Muscovite granite from Harney Peak, South Dakota; J. Geophys. Res., 86 1,0151,029 
Huerta A D, Royden L H and Hodges K V 1998 The thermal structure of collisional orogens; J. Geophys. Res., 103 $15,287-15,302$

Hutton D H W 1988 Granite emplacement mechanisms and tectonic controls: Inferences from deformation studies; Trans. R. Soc. Edinburgh: Earth Sci., 79 245-255

Jamieson R A, Beaumont C, Fullsack P and Lee B 1998 Barrovian regional metamorphism: Where's the heat? In: What drives metamorphism and metamorphic reactions (eds.) P J Treloar and P J O'Brien. Geol. Soc. Spec. Publ., $13823-51$

Jones K A and Brown M 1990 High-temperature 'clockwise' $\mathrm{P}-\mathrm{T}$ paths and melting in the development of regional migmatites: an example from southern Brittany, France; J. metamorphic Geol., 8 551-578

Kay S M and Rapela C W 1990 Plutonism from Antarctica to Alaska; Geol. Soc. Amer., Spec. Paper, 241 pp. 263

Kays M A 1970 Mesozoic metamorphism, May Creek Schist Belt, Klamath Mountains, Oregon; Geol. Soc. Amer. Bull., 81 2743-2758

Kriegsman L M 2001a Partial melting, partial melt extraction and partial back reaction in anatectic migmatites; Lithos, 56 75-96

Kriegsman L M 2001b Quantitative field methods for estimating melt production and melt loss; Phys. Chem. of the Earth., 26 247-253

Kriegsman L M and Hensen B J 1998 Back reactions between restite and melt: Implications for geothermobarometry and pressure-temperature paths; Geology, 26 1111-1114

Laporte D, Rapaille C and Provost A 1997 Wetting angles, equilibrium melt geometry, and the permeability threshold of partially-molten crustal protoliths. In: Granites: From Segregation of Melt to Emplacement Fabrics (eds.) J L Bouchez, D H W Hutton and W E Stephens The Netherlands: Kluwer Academic Publishers, pp. 31-54

Lathrop A S, Blum J D and Chamberlain C P 1996 Nd, $\mathrm{Sr}$ and $\mathrm{O}$ isotopic study of the petrogenesis of two syntectonic members of the New Hampshire Plutonic Series; Contrib. Mineral. Petrol., 124 126-138

LeBreton N and Thompson A B 1988 Fluid-absent (dehydration) melting of biotite in metapelites in the early stage of crustal anatexis; Contrib. Mineral. Petrol., 99 226-237

Ledru P and 13 others 2000 Anatomy of the Velay Massif (French Massif Central): A case history of conditions of melt generation and granite emplacement at the end of an orogeny; Tectonophysics, $\mathbf{3 4 2}$ 000-000

LeFort P 1986 Metamorphism and magmatism during the Himalayan collision. In: Collision Tectonics (eds.) M P Coward and A C Ries. Geol. Soc. Spec. Publ., 19 159172

Leitch A M and Weinberg R F 2000 Mesoscale pervasive flow model for granite magma migration; European Geophysical Society, 25th general assembly Geophysical Research Abstracts 2 (2000) CD-ROM

Leloup P H, Ricard Y, Battaglia J and Lacassin R 1999 Shear heating and continental strike-slip shear zones: model and field examples; Geophys. J. Int., 136 19-40

Luais B and Hawkesworth C J 1994. The generation of continental crust: An integrated study of crust-forming processes in the Archean of Zimbabwe; J. Petrol., 35 4393

Marchildon N and Brown M 2001 Melt segregation in late-tectonic anatectic migmatites: an example from the Onawa contact aureole, Maine, U.S.A; Phys. Chem. of the Earth, 26 225-229

McCaffrey K J W and Petford N 1997 Are granitic intrusions scale invariant?; J. Geol. Soc., London, 154, 1-4
McLellan E L 1989 Sequential formation of sub-solidus and anatectic migmatites in response to thermal evolution, eastern Scotland; J. Geol., 97 165-182

Miller R B and Paterson S R 1999 In defense of magmatic diapirs; J. Struct. Geol., 21 1161-1173

Miller S A and Nur A 2000 Permeability as a toggle switch in fluid-controlled crustal processes; Earth and Planet. Sci. Let., 56, 75-96

Milord I, Sawyer E W and Brown M 2000 Formation of diatexite migmatites and granite magma during anatexis of metasedimentary rocks: An example from St. Malo, France; J. Petrol., 42 487-505

Mogk D W 1990 A model for the granulite-migmatite association in the Archean basement of southwestern Montana. In: Granulites and crustal evolution (eds.) D Vielzeuf and Ph. Vidal, The Netherlands: Kluwer Academic Publishers, pp. 133-55

Mogk D W 1992 Ductile shearing and migmatization at mid-crustal level in an Archean high-grade gneiss belt, northern Gallatin Range, Montana, USA; J. metamorphic Geol., 10 427-438

Molnar P and England P 1990 Temperatures, heat flux, and frictional stress near major thrust faults; J. Geophys. Res., 95 4833-4856

Nabelek P I and Liu M 1999 Leucogranites in the Black Hills of South Dakota: The consequence of shear heating during continental collision; Geology, 27 523-526

Nelson K D and 27 others 1996 Partially molten middle crust beneath southern Tibet: Synthesis of project INDEPTH results. Science, 174 1,684-1,688

Nyman M W, Pattison D R M and Ghent E D 1995 Melt extraction during formation of K-feldspar + sillimanite migmatites, west of Revelstoke, British Columbia; J. Petrol. 36 351-372

Ord A and Hobbs B E 1989 Strength of the continental crust, detachment zones and the development of plastic instabilities; Tectonophysics, 158 269-289

Park Y and Means W D 1996 Direct observation of deformation processes in crystal mushes; J. Struct. Geol., 18 $847-858$

Partzsch G M , Schilling F R and Arndt J 2000 The influence of partial melting on the electrical behavior of crustal rocks: laboratory examinations, model calculations and geological interpretations; Tectonophysics, 317 189-203

Paterson M S 2001 A granular flow theory for the deformation of partially-molten rock; Tectonophysics, 335 51-61

Paterson S R and Fowler T K, Jr. 1993 Re-examining pluton emplacement processes; J. Struct. Geol., 15 191-206

Paterson S R and Schmidt K L 1999 Is there a spatial relationship between faults and plutons? J. Struct. Geol., 21 1131-1142

Paterson S R and Vernon R H 1995 Bursting the bubble of ballooning plutons: A return to nested diapirs emplaced by multiple processes; Geol. Soc. Amer. Bull., 107 13561380

Paterson S R, Fowler T K, Jr. and Miller R B 1996 Pluton emplacement in arcs: A crustal-scale exchange process; Trans. R. Soc. Edinburgh: Earth Sci., 87 115-123

Patiño Douce A E 1999 What do experiments tell us about the relative contributions of crust and mantle to the origin of granitic magmas? Understanding Granites. Integrating new and classical techniques (eds. A Castro, C Fernandez and J L Vigneresse). Geol. Soc. Spec. Pub., 158 $55-75$

Patiño Douce A E and Harris N 1998 Experimental constraints on Himalayan anatexis; J. Petrol., 39 689-710

Petford N and Koenders M A 1998a Granular flow and viscous fluctuations in low Bagnold number granitic magmas; J. Geol. Soc., London, 155 873-881 
Petford N and Koenders M A 1998b Self-organisation and fracture connectivity in rapidly heated continental crust; J. Struct. Geol., 20 1425-1434

Petford N, Cruden A R, McCaffrey K J W and Vigneresse J L 2000 Granite magma formation, transport and emplacement in the Earth's crust; Nature, 408 669-673

Petö P 1976 An experimental investigation of melting relations involving muscovite and paragonite in the silicasaturated portion of the system $\mathrm{K}_{2} \mathrm{O}-\mathrm{Na}_{2} \mathrm{O}-\mathrm{SiO}_{2}-$ $\mathrm{H}_{2} \mathrm{O}$ to $15 \mathrm{kbar}$ total pressure; Progress in Experimental Petrology, NERC, London, 3 41-45

Pitcher W S 1993 The nature and origin of granite. Blackie A. and P., An imprint of Chapman \& Hall

Powell R and Downes J 1990 Garnet porphyroblast-bearing leucosomes in metapelites: Mechanisms, phase diagrams, and an example from Broken Hill, Australia, In: Hightemperature metamorphism and crustal anatexis (eds.) J R Ashworth and M Brown The Mineralogical Society Series: 2. Unwin Hyman, London, pp. 105-123

Pressley R A and Brown M 1999 The Phillips Pluton, Maine, USA: Evidence of heterogeneous crustal sources, and implications for granite ascent and emplacement mechanisms in convergent orogens; Lithos, 46 335-366

Raith M, Karmakar S and Brown M 1997 Ultrahightemperature metamorphism and multi-stage decompressional evolution of sapphirine granulites from the Palni Hill Ranges, Southern India; J. metamorphic Geol. 15 379-399

Rapp R P and Watson E B 1995 Dehydration melting of metabasalt at 8-32 kbar: Implications for continental growth and crust-mantle recycling; J. Petrol., 36 891-931

Renner J, Evans B and Hirth G 2000 On the rheologically critical melt fraction; Earth and Planet Sci. Let., 181 585-594

Rosenberg C L and Handy M R 2000a Syntectonic melt pathways during simple shearing of an anatectic rock analogue (norcamphor-benzamide); J. Geophys. Res., 105 3135-3149

Rosenberg C L and Handy M R 2000b Melt migration during pure shear deformation of a partially molten rock analogue (norcamphor-benzamide); J. Struct. Geol., 00 000-000

Rosenberg C L and Riller U 2000 Partial-melt topology in statically and dynamically recrystallized granite; Geology, 28 7-10

Royden L H 1993 The steady-state thermal structure of eroding orogenic belts and accretionary prisms; J. Geophys. Res., 98 4,487-4,507

Rudnick R L 1992 Xenoliths-Samples of the lower continental crust. In: Continental Lower Crust (eds.) D M Fountain, R Arculus and R W Kay. (New York: Elsevier Sci.), pp. 269-316

Rudnick R L and Fountain D M 1995 Nature and composition of the continental crust: a lower crustal perspective; Rev. of Geophys., 33 267-309

Rudnick R L and Presper T 1990 Geochemistry of intermediate- to high-pressure granulites. In: Granulites and Crustal Evolution (eds.) D Vielzeuf and P Vidal. Kluwer Academic Publishers, The Netherlands, pp. 523550

Rushmer T 2001 Volume change during partial melting reactions: implications for melt extraction, melt geochemistry and crustal rheology; Tectonophysics, 342 000-000

Rutter E H 1997 The influence of deformation on the extraction of crustal melts: A consideration of the role of meltassisted granular flow. In: Deformation-Enhanced Fluid Transport in the Earth's Crust and Mantle (ed.) M B Holness The Mineralogical Society Series, 8 Chapman and Hall, London, pp. 82-110
Sawyer E W 1994 Melt segregation in the continental crust; Geology, 22 1,019-1,022

Sawyer E W 1996 Melt segregation and magma flow in migmatites: implications for the generation of Granite magmas; Trans. R. Soc. Edinburgh: Earth Sci., 87 85-94

Sawyer E W 1998 Formation and evolution of granitic magmas during crustal reworking: the significance of diatexites; J. Petrol., 39 1147-1167

Sawyer E W 1999 Criteria for the recognition of partial melting; Phys. Chem. Earth, (A) 24 269-279

Sawyer E W 2001 Melt segregation in the continental crust: distribution and movement of melt in anatectic rocks; $J$. metamorphic Geol., 19 291-309

Sawyer E W and Barnes S-J 1988 Temporal and compositional differences between subsolidus and anatectic migmatite leucosomes from the Quetico metasedimentary belt, Canada; J. metamorphic Geol., 6 437-450

Schnetger B 1994 Partial melting during the evolution of the amphibolite- to granulite-facies gneisses of the Ivrea zone, northern Italy; Chem. Geol., 113 71-101

Scholz C H 1980 Shear heating and the state of stress on faults; J. Geophys. Res., 85 6174-6184

Snoke A W, Kalakay T J, Quick J E and Sinigoi S 1999 Deep-crustal shear zone as a result of mafic igneous intrusion in the lower crust, Ivrea-Verbano Zone, Southern Alps, Italy; Earth Planet. Sci. Lett., 166 31-45

Solar G S and Brown M 1999. The classic high- $T$ - low- $P$ metamorphism of west-central Maine, USA: Is it posttectonic or syn-tectonic? Evidence from porphyroblastmatrix relations; Can. Mineral., 37 289-311

Solar G S and Brown M 2001a Deformation partitioning during transpression in response to Early Devonian oblique convergence, Northern Appalachian orogen, USA; J. Struct. Geol., 23 1043-1065

Solar G S and Brown M 2001b Petrogenesis of Migmatites in Maine, USA: Possible Source of Peraluminous Granite in Plutons; J. Petrol., 42 789-823

Solar G S, Pressley R A, Brown M and Tucker R D 1998 Granite ascent in convergent orogenic belts: testing a model; Geology, 26 711-714

Stevens G 1997 Melting, carbonic fluids and water recycling in the deep crust: An example from the Limpopo belt, South Africa; J. metamorphic Geol., 15 141-154

Stevens G and Van Reenen D 1992. Partial melting and the origin of metapelitic granulites in the Southern Marginal Zone of the Limpopo Belt, South Africa; Precambrian Res., 55 303-319

Tanner D C 1999 The scale-invariant nature of migmatite from the Oberpfalz, NE Bavaria and its significance for melt transport; Tectonics, 302 297-305

Thompson A B 1996 Fertility of crustal rocks during anatexis; Trans. R. Soc. Edinburgh: Earth Sci., $\mathbf{8 7}$ $1-10$

Thompson A B 1999 Some time-space relationships for crustal melting and granitic intrusion at various depths. In: Understanding Granites: Integrating New and Classical Techniques, (eds.) A Castro, C Fernåndez and J L Vigneresse Geol. Soc. Spec. Publ. 168 7-25

Thompson A B 2001a Clockwise P-T paths for crustal melting and $\mathrm{H}_{2} \mathrm{O}$ recycling in granite source regions and migmatite terrains; Lithos, 56 33-45

Thompson A B 2001b $P$ - $T$ paths, $\mathrm{H}_{2} \mathrm{O}$ recycling, and depth of crystallization for crustal melts; Phys. Chem. of the Earth, 26 231-237

Thompson A B, Schulmann K and Jezek J 1997 Thermal evolution and exhumation in obliquely convergent (transpressive) orogens; Tectonophysics, 280 171-184

Thompson A B, Tracy R J 1979 Model systems for anatexis of pelitic rocks; Contrib. Mineral. Petrol., 70 429-438 
Vanderhaeghe O 1999 Pervasive melt migration from migmatites to leucogranite in the Shuswap metamorphic core complex, Canada: Control of regional deformation; Tectonophysics, 312 35-55

Vanderhaeghe O and Teyssier C 2001 Partial melting and flow of orogens; Tectonophysics, 342 000-000

Vanderhaeghe O, Burg J -P and Teyssier C 1999 Exhumation of migmatitic terrains in two collapsed orogens: Canadian Cordillera and French Variscides. In: Exhumation processes: Normal faulting, ductile flow and erosion (eds.) U Ring, M T Brandon, G S Lister and S D Willet Geol. Soc. Spec. Publ. 154 181-204

Vernon R H 1999 Quartz and feldspar microstructures in metamorphic rocks; Can. Mineral., 37 513-524

Vernon R H and Collins W J 1988 Igneous microstructures in migmatites; Geology, 16 1,126-1,129

Vernon R H and Paterson S R 2000 Axial-surface leucosomes in anatectic migmatites; Tectonophysics, 335 183-192

Vielzeuf D, Clemens J D, Pin C and Moinet E 1990 In: Granites, granulites, and crustal differentiation (eds.) D Vielzeuf and Vidal, Ph.) Granulites and Crustal Evolution. Kluwer Academic Publishers, The Netherlands, pp. 59-85

Vielzeuf D, Montel J M 1994 Partial melting of metagreywackes. Part I. Fluid-absent experiments and phase relationships; Contrib. Mineral. Petrol., 117 375-393

Vielzeuf D and Vidal P 1990 Granulites and crustal evolution. Kluwer Academic Publishers, The Netherlands,

von Blanckenburg F and Davies J H 1995 Slab breakoff: A model for syncollisional magmatism and tectonics in the Alps; Tectonics, 14 120-131
Waters D J 1988 Partial melting and the formation of granulite facies assemblages in Namaqualand, South Africa; J. metamorphic Geol., 6 387-404

Watt G R, Oliver N H S and Griffin B J 2000 Evidence for reaction-induced microfracturing in granulite facies pelitic migmatites; Geology, 28, 331-334

Weber C, Barbey P, Cuney M and Martin H 1985 Trace element behavior during migmatization. Evidence for a complex melt-residuum-fluid interaction in the St. Malo migmatitic dome (France); Contrib. Mineral. Petrol., 90 $52-62$

Weinberg R F 1999 Pervasive felsic magma migration: alternatives to diking? Lithos, 41 393-410

Weinberg R F, Sial A N and Pessoa R R Magma flow within the Tavares pluton, NE Brazil: Compositional and thermal convection. Geol. Soc. Amer. Bull., 113 508520

Williamson B J, Downes H, Thirlwall M J and Beard A 1997 Geochemical constraints on restite composition and unmixing in the Velay anatectic granite, French Massif Central; Lithos, 40 295-319

Yardley B W D and Valley J W 1997 The petrologic case for a dry lower crust; J. Geophys. Res., 102 1217312185

Zeck H P 1970 An erupted migmatite from Cerro del Hoyazo, SE Spain; Contrib. Mineral. Petrol., 26 225246

Zeck H P 1996 Betic-Rif orogeny: Subduction of Mesozoic Tethys under E-ward drifting Iberia, slab detachment shortly before $22 \mathrm{Ma}$, and subsequent uplift and extensional tectonic; Tectonophysics, 254 1-16 